\title{
Ecomimicry in Indigenous resource management: optimizing ecosystem services to achieve resource abundance, with examples from Hawai $i$
}

\author{
$\underline{\text { Kawika B. Winter }}^{1,2,3,4}$, Noa Kekuewa Lincoln ${ }^{5}$, Fikret Berkes $^{6}, \underline{\text { Rosanna A. Alegado }}^{7,8}, \underline{\text { Natalie Kurashima }}^{9}, \underline{\text { Kiana L. Frank }}^{10}$,

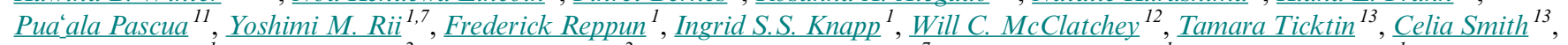 \\ $\underline{\text { Erik C.Franklin }}^{1}, \underline{\text { Kirsten Oleson }}^{2}, \underline{\text { Melissa R.Price }}^{2}$, Margaret A. McManus $^{7}$, Megan J. Donahue ${ }^{1}, \underline{\text { Kuulei S. Rodgers }}{ }^{1}, \underline{B r i a n}_{W}$ \\ $\underline{\text { Bowen }}^{1}, \underline{\text { Craig E. Nelson }}^{7,8}, \underline{\text { Bill Thomas }}^{14}, \underline{\text { Jo-Ann Leong }}^{1}, \underline{\text { Elizabeth M. P. Madin }}^{1}, \underline{\text { Malia Ana J.Rivera }}{ }^{1}, \underline{\text { Kim A A Falinski }}^{15}, \underline{\text { Leah }}^{1}$

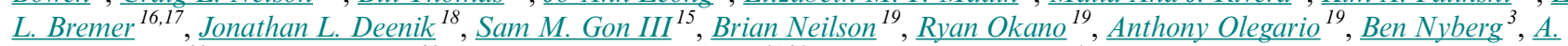 \\ $\underline{\text { Hi ilei Kawelo }}^{20}$, Keli i Kotubetey $^{20}, \underline{\text { J. Känekoa Kukea-Shultz }}^{15,21}$ and Robert J. Toonen $^{1}$
}

\begin{abstract}
Here, we expand on the term "ecomimicry" to be an umbrella concept for an approach to adaptive ecosystem-based management of social-ecological systems that simultaneously optimizes multiple ecosystem services for the benefit of people and place. In this context, we define ecomimicry as a strategy for developing and managing cultural landscapes, built upon a deep understanding of the structure and function of ecosystems, that harnesses ecosystem processes for the purpose of balancing and sustaining key ecosystem services, rather than maximizing one service (e.g., food production) to the detriment of others. Ecomimicry arises through novel, place-based innovations or is adopted from elsewhere and adapted to local conditions. Similarly, precontact Hawaiian socialecological systems integrated a variety of ecomimicry schema to engender a complex system of adaptive resource management that enhanced biocultural diversity and supported resilient food systems, ultimately sustaining a thriving human population. In addition to presenting a synopsis of how ecomimicry was employed in the design and management of Hawaiian social-ecological systems, we identify and characterize specific ecomimicry applications. Within this context, we explore a revival of ecomimicry for biological conservation, biocultural restoration, resilience, and food security. We conclude with a discussion of how revitalizing such an approach in the restoration of social-ecological systems may address issues of conservation and sustainability in the Anthropocene.
\end{abstract}

Key Words: agroecology; ecosystem-based management; Hawaiian resource management; social-ecological systems theory

\section{INTRODUCTION}

Ecosystem-based management is a long-term, integrated management approach that recognizes that humans are a necessary part of, and have significant influences on, their environments. It embodies a fundamental shift away from ineffective conventional management paradigms that are frequently short term, reactionary, suffer jurisdictional limitations, consider humans to be independent of nature, and view human presence as incompatible with conservation goals (McLeod and Leslie 2009). Ecosystem-based management, however, is not an entirely novel perspective. Indigenous peoples have, since time immemorial, holistically managed human-innature systems (Berkes 2018), termed herein as social-ecological systems (Berkes and Folke 1998). Understanding the dynamics of such systems and the results of various approaches to systemlevel management is essential to addressing issues of sustainability.

Issues of sustainability, both locally and globally, can be viewed through the lens of ecosystem services, which are the myriad benefits provided by ecosystems that collectively compose the foundation of human societies, civilizations, and humanity itself
(Díaz et al. 2018). Ecosystem services support human well-being at the scale of extended families and communities by contributing to linked physical, spiritual, and mental health (Pascua et al. 2017). This perspective is particularly relevant in the Anthropocene, in which expanding human demands on natural resources have created a variety of environmental and societal problems across multiple dimensions (e.g., Rockström et al. 2009, Lewis and Maslin 2015, Sterling et al. 2017). Ecosystem services are reciprocal in social-ecological systems and include the services that human societies provide to nature (Comberti et al. 2015). Here, we posit human management strategies and associated behaviors as "drivers" that can maintain, increase, or decrease ecosystem services (Nelson et al. 2006), rather than characterizing so-called "human impacts" as inherently negative influences on the structure and function of ecosystems and ecological processes. Our premise is that human management of social-ecological systems has the potential to drive a broad spectrum of ecosystem services in multiple directions.

\section{Reconceptualizing ecomimicry}

While the notion of incorporating functional components and processes of an ecosystem into human-made systems has been

\footnotetext{
${ }^{1}$ Hawai i Institute of Marine Biology, University of Hawai'i at Mānoa, ${ }^{2}$ Natural Resources and Environmental Management, University of Hawai i at Mānoa, ${ }^{3}$ National Tropical Botanical Garden, ${ }^{4}$ Hawai i Conservation Alliance, ${ }^{5}$ Tropical Plant and Soil Sciences Department, University of Hawai i i at Mānoa, ${ }^{6}$ Natural Resources Institute, University of Manitoba, ${ }^{7}$ Department of Oceanography, University of Hawai i i at Mānoa, ${ }^{8}$ University of Hawai'i Sea Grant College Program, University of Hawai'i at Mānoa, ${ }^{9}$ Natural and Cultural Resources, Kamehameha Schools, ${ }^{10}$ Pacific Biosciences Research Center, Kewalo Marine Lab, University of Hawai'i at Mānoa, ${ }^{11}$ Center for Biodiversity and Conservation, American Museum of Natural History, ${ }^{12}$ Woodland Valley Meadows Farm, ${ }^{13}$ School of Life Sciences, University of Hawai'i at Mānoa, ${ }^{14}$ Office for Coastal Management, National Oceanic and Atmospheric Administration, ${ }^{15}$ The Nature Conservancy of Hawai i, ${ }^{16}$ University of Hawai'i Economic Research Organization, University of Hawai i at Mānoa, ${ }^{17}$ Water Resources Research Center, University of Hawai i at Mānoa, ${ }^{18}$ Tropical Plants and Soil Sciences, University of Hawai'i at Mānoa, ${ }^{19}$ Division of Aquatic Resources, Hawai'i Department of Land and Natural Resources, ${ }^{20}$ Paepae o He'eia, ${ }^{21}$ Kāko‘o 'Ōiwi
} 
articulated previously, these treatments have been limited in application to design principles. For example, "ecological engineering" describes the purposeful design of ecosystems for the mutual benefit of humans and nature (Mitsch 2012); more recently, "ecomimicry" has been used to refer to the design of technology or other built systems in the modern era that imitate or are inspired by nature (Yeang 2013, Blok 2017). Of these terms, we argue for broadening the concept of ecomimicry to encompass human-managed systems such as multifaceted ecosystem-based resource management of social-ecological systems, which includes embedded forms of agroecology. It is the methodology that humans employ to act as ecosystem engineers within the context of the opportunities and constrains of a given landscape.

Notably, management practices centered around ecomimicry have been perpetuated by Indigenous peoples for millenia. Indigenous societies incorporated the function of nature into the structure of social-ecological systems (Winter et al. 2018b), the outward appearance of which is a "cultural landscape" that has integrated humanity and nature into a single system (Molnar and Berkes 2018). Examples include the rice-fish systems in Southeast Asia (Berkes 2018) and tropical agroforestry systems (Ticktin et al. 2018). These systems are predicated on the holistic and collective understanding of individual ecosystems that balances trade-offs between food production and foundational ecosystem functions.

In contrast to some forms of ecological engieering in which diversity is not necessarily a prerequisite, the success of ecomimicry relies on biodiversity. This premise is because biodiversity is the foundation of biocultural diversity, or the variety of connections between humanity and nature (Winter and McClatchey 2008, Winter et al. 2018b, Chang et al. 2019a). In systems managed by Indigenous cultures that have conceptually placed themselves as a part of nature, biocultural diversity is critical to fostering resilience of social-ecological systems by maintaining flexibility and options to deal with change (Chan et al. 2016, Winter et al. 2018b). An example is Hawaiian culture, which demonstrates numerous long-standing mechanisms within its approaches to resource management that emulate ecosystem processes. These mechanisms are used to stabilize, expand, or otherwise modify local-scale habitats to drive increases in the abundance and reliable availability of essential resources (Kealiikanakaoleohaililani et al. 2018, Gould et al. 2019). The 20th century saw a substantial shift away from Indigenous management strategies such as ecomimicry and philosophies associated with Hawaiian social-ecological systems. A simultaneous shift toward centralized governance led to decreased appreciation of connectivity among resources (Winter et al. 2018a), and agency jurisdiction silos reinforced this trend. This shift has resulted in a decline in forest habitat in the modern era to only $34 \%$ of its original extent (Jacobi et al. 2017) and an increase in imports to $80-90 \%$ of food for the 1.4 million residents of Hawai'i (Loke and Leung 2013). Concurrently, proliferation of invasive species, increasing urbanization, commercialization of resource extraction, and policies for coastal development and flood control increased the rate of environmental change and species loss across the landscape (Ziegler 2002).
The return to ecomimicry as a global solution for conservation and sustainability

Hawai $i$ faces many complex problems such as habitat degradation and loss, a growing list of extinct and endangered species, increasing demand for food from farming and fishing, overexploitation of natural resources, and an ever-expanding urban footprint with associated pollution issues. In the face of these challenges, we provide a broad synopsis of how ecomimicry, as an approach to landscape-scale biocultural resource management, has been implemented within Hawaiian socialecological systems, and how various forms of ecomimicry can be revitalized to address issues of conservation and sustainability across the globe in the Anthropocene. In this regard, we aim to synthesize some aspects of Indigenous resource management that have driven increases in the outputs of ecosystem services while maintaining overall system stability and minimizing ecosystem disservices. The concepts explored herein can thus inform efforts to restore the health and function of social-ecological systems in the most remote archipelago on Earth. We also create a framework within which Indigenous science and conventional science can collaborate to inform both local and global policy for a more sustainable future. Although we focus on the past development and subsequent management of various forms of ecomimicry in Hawaiian social-ecological systems, it is important to note that many traditional and customary practices of Native Hawaiians persist today (McGregor 2007), and others are in the process of being revitalized in the continuing renaissance of Hawaiian culture (e.g., Chang et al. 2019a, Gon and Winter 2019).

\section{Ecomimicry and associated ethics within Hawaiian social- ecological systems \\ Hawaiian resource management systems}

Hawai'i's diverse ecological and climatic zones have faciliated a plethora of management regimes (Handy et al. 1972, Winter and Lucas 2017), which provide unique opportunities for examining how distinct landscapes shaped management practices. This influence is evident in an examination of the moku system, the resource management system that was developed to manage Hawaiian social-ecological systems in the precontact era (Winter et al. 2018a). The moku system is an example of landscape-scale ecomimicry in that it is a system that created divisions of land with ecologically based zones, and boundaries that ran both horizontally (e.g., along rainfall gradients) and vertically (e.g., along ridgelines) to create a mosaic that integrated forests and waterscapes into cultural landscapes. Moku (social-ecological region) boundaries were aligned with ecoregions to facilitate effective management of the connectivity and population dynamics of important species on a habitat scale (Fig. 1; Winter et al. 2018a). Recent research into the genetic structure and population connectivity of both terrestrial and coral reef organisms support moku as the most appropriate spatial scale for the management of population dynamics (Cowie and Holland 2008, Selkoe et al. 2016, Coleman 2019).

Each moku was subdivided into several ahupua'a (socialecological community). The ahupua' $a$ was a key unit of resource management and governance, the boundaries of which generally extended from the mountains to the sea (Gonschor and Beamer 2014). Ahupua' a residents could only rely on resources from within 
Fig. 1. A schematic model (A) and a spatial model (B) depicting the layout of a single social-ecological region (moku) based on the Hawaiian social-ecological system on the island of Kaua i. (A) The terrestrial and oceanic social-ecological zones and their subcategories are oriented horizontally. Ahupua'a or social-ecological communities are oriented vertically. (B) The moku of Halele'a encompasses numerous ahupua'a, each with jurisdiction over a full spectrum of terrestrial and oceanic social-ecological zones within its boundaries. Data for this figure came from Winter et al. $2018 b$.

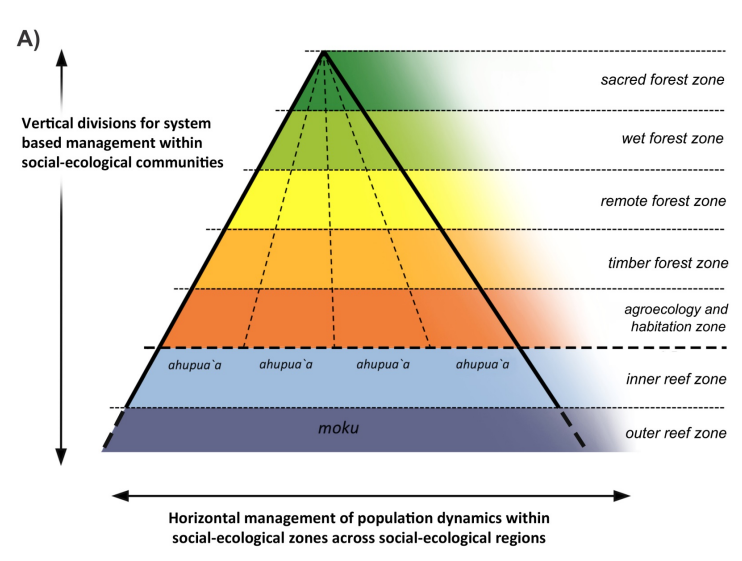

the bounds of their social-ecological community to live. The difference between surviving and thriving over the course of several generations within the bounds of an ahupua' $a$ hinged on maintaining the integrity of all habitats, which were the sources of ecosystem services. All habitats within a social-ecological community needed to be maintained and managed to optimize a broad range of ecosystem services available to residents of the social-ecological community. Specific forms of local-scale ecomimicry were integrated into ahupua' $a$ design as a means to maximize key ecosystem services such as food production, freshwater availability, timber and nontimber forest products, and biodiversity (Handy et al. 1972, Minton and Nā Maka o ka 'Āina 1992). Although the proportionality of habitats within ahupua'a may have shifted through the implementation of various forms of ecomimicry (e.g., the proportion of forest cover decreased and the proportion of wetland cover increased), no habitat types were outright destroyed within ahupua'a because that would have resulted in decreases in much-needed ecosystem services for the human community. The maintenance of these habitats was achieved via the designation of social-ecological zones that ran as belts that traversed the moku so that habitats and the connectivity of native diversity could be managed accordingly (Fig. 1). Concurrently, sociocultural institutions cultivated a body of philosophy, ethics, and associated values needed to hold these Indigenous resource management systems together.

\section{Role of sociocultural institutions in resource management systems}

In Hawaiian social-ecological systems, cognitive approaches to the physical management of various habitat types were integrated as central philosophies within sociocultural institutions that resulted in resilience and food security (Winter et al. 2018b). For example, forests provided the majority of the material resources that were the building blocks of Hawaiian culture and society (Abbott 1992), and extensive rain-fed agroforestry systems provided additional food sources (Lincoln et al. 2018, Kurashima et al. 2019, Quintus et al. 2019). Streams were important sources

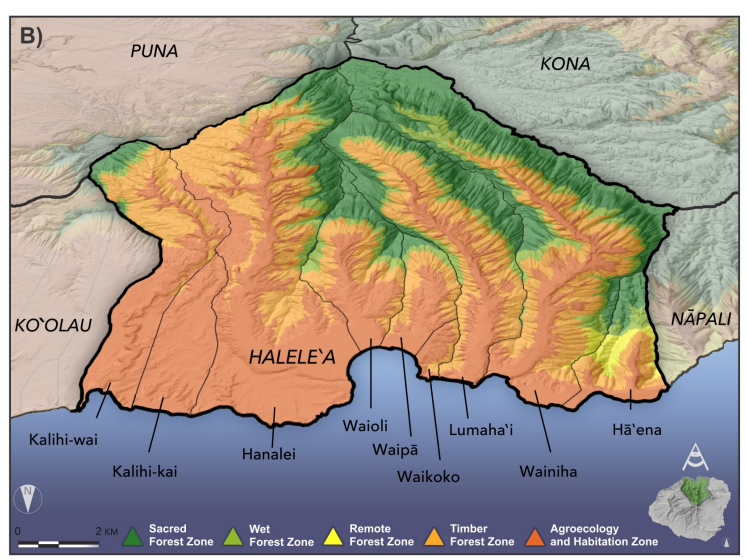

of fresh drinking water and, therefore, were foundational to healthy social-ecological systems. Furthermore, they provided important components of food systems (e.g., shellfish and finfish; Maly and Maly 2003b, Winter et al. 2018a). Shallow marine habitats in Hawai $i$ host $>300$ species of native marine organisms documented as food sources, comprising vertebrates, invertebrates, and macroalgae (Maly and Maly 2003b). This biocultural diversity, along with a complex system of regulations aimed at managing population dynamics and species connectivity, facilitated resilience in the food system and augmented food security (Winter et al. 2018a). The perceived value of the biocultural diversity within these systems was increased and maintained through sociocultural institutions.

Biocultural diversity can be quantified at a landscape scale. Cultural landscapes of high biocultural value can be considered "critical cultural habitat" for Indigenous peoples because they facilitate the existence and perpetuation of intergenerational human-nature relationships (Winter et al. 2020), termed herein as "biocultural traditions." These biocultural traditions promote sociocultural investment in biodiversity, thus providing a feedback loop (Sterling et al. 2017, Berkes 2018). Key to the success of such feedback loops is the presence of appropriate sociocultural institutions that provide the structure and philosophical foundation for humans to be protectors, rather than exploiters, of ecosystem products (Ostrom 1990, Colding et al. 2003, Kurashima et al. 2018). In this sense, systematic local-scale implementation of ecomimicry as a biocultural resource management system is shaped by those same sociocultural institutions (Berkes 2018).

Sociocultural institutions within Hawaiian social-ecological systems embraced a general philosophy that the health of the ocean is affected by the health of the land, and vice versa, as well as an ethic of taking only what one needs for the day, while leaving more for tomorrow (Pukui et al. 1972, Pukui 1983). Sociocultural institutions also regulated and enforced resource extraction via 
laws and religion (Handy et al. 1972, Winter et al. 2018a). This holistic philosophy maintained the concept of connectivity and interdependence (e.g., between forests and coral reefs, and among resource users) in the forefront of the community's consciousness, and it influenced the development of communities as well as the agroecology systems needed to sustainably support them.

\section{Agroecology systems}

At the landscape scale, agroecology is the science and practice of sustainable agriculture based on ecological principles (Gliessman 2014, Young 2017). We contend that agroecology is an approach to ecomimicry focused on sustainable resource production (e.g., food, timber, and nontimber forest products) that operated on a landscape scale and, in Hawai i, was embedded within the context of the moku system. Here, we examine how agroecology used general habitat types managed within Hawaiian social-ecological systems. Part of the success of this approach was in substituting species that occupied a similar niche, in terms of both functional and structural diversity, to increase the biocultural diversity of a landscape while maintaining ecosystem structure and function, a resilience strategy based on redundancy (Van Looy et al. 2019). We will explore this concept, as well as how disturbance and ecological succession, referred to herein as "disturbance regimes", were managed both in stable habitat types (e.g., forests, streams, and reefs) and in transitional habitat types (e.g., wetlands and estuaries) to increase species richness and overall abundance on a localized scale. Hawaiian social-ecological system design managed disturbance regimes to increase food abundance, biocultural diversity, and other ecosystem services in ways that minimized uncertainty and increased resilience. An examination of the moku and ahupua'a scales, in particular, provides examples of how this approach to ecomimicry can be used to turn problems (e.g., terrestrial sediment and nutrient run-off) into mitigated solutions for other issues within the same watershed (e.g., crop needs for topsoil and nutrients). In Hawaiian social-ecological systems, agroecology for crop production has three main forms: intensive wetland fields, intensive rain-fed fields, and other extensively rainfed systems (Lincoln and Vitousek 2017, Winter et al. 2018b, Kurashima et al. 2019).

Transitional zones of confluence between two relatively stable habitats was a focal point of Hawaiian agroecology. Such zones are often associated with corresponding edge effects, which create additional environmental niches that facilitate an increase in biodiversity (Attrill and Rundle 2002, Brownstein et al. 2015). Disturbance is a key aspect of such confluence zones, and agroecology systems used this fact to their advantage. The presence of plants and animals that specialize in these transient disturbed habitats further elevate biodiversity, as predicted by Connell's (1978) intermediate disturbance hypothesis. Species within these environments are evolutionarily selected for thriving in the context of disturbance regimes (Van Looy et al. 2019), e.g., the ability of native waterbirds to re-nest following flooding events and the ability of native sedges to re-emerge as sediments shift.

Such edges are critical to the resilience of social-ecological systems (Turner et al. 2003). An example of this in Hawaiian socialecological systems is the riparian and adjacent wetland system, which is a key confluence zone, or ecotone, between lotic (flowing water) and terrestrial habitats. These areas are frequently disturbed by flood events, which affect stream and riparian landscapes alike, producing a shifting mosaic of disturbance patches (Nakamura et al. 2000) and spreading nutrient-laden sediment over the landscape (Junk et al. 1989). Another example of an edge habitat is the estuary systems where freshwater mixes with saltwater, which tend to be nutrient rich and productive relative to surrounding areas. Below, we will explore how disturbance was managed and used in Hawaiian social-ecological systems to increase food production and other ecosystem services in these edge environments.

The templates for various forms of agroecology were transported to the Hawaiian Islands by Polynesian voyagers, but the regional variation in environmental diversity, native species diversity, and agricultural potential led to unique adaptations of design that operated within the opportunities and constraints of local landscapes and their processes (Lincoln and Vitousek 2017, Lincoln et al. 2018). This customized design application was exemplified by the ecologically defined planting regimes applied to rain-fed agriculture (Lincoln and Ladefoged 2014, Lincoln et al. 2014), temporal movement of cultivation areas (Lee et al. 2006, Kagawa-Viviani et al. 2018), and the changing form and function of agroforestry (Lincoln 2020) that maximized nutrient and resource flows to enhance food production while simultaneously providing for both biocultural traditions and other ecosystem services. Examples of such customized design will be explored next. These approaches to agroecology paved the way to attain the state of sustainable resource abundance ('aina momona, literally "fat land") by producing a greater abundance of key resource species (e.g., native shellfish, fish, and waterfowl) in the system than would exist without intentional human intervention. Such is the legacy of Hawaiian social-ecological systems (Winter et al. 2018a, Chang et al. 2019a).

Beyond providing food, agroecology infrastructure cumulatively benefited both the environment and human communities (Baulcomb et al. 2015). Ethics were reinforced through practice and interaction with the biocultural landscape. In many cases, Hawaiian communities worked together to engineer and construct landscape-scale ecomimicry projects that provided ecosystem services such as sediment and nutrient retention to protect downstream systems (e.g., nearshore reefs). Construction of such infrastructure also enhanced social integration (Scheffler and Lockwood 2014). The physical labor required for construction, restoration, and maintenance of physical infrastructure built strong social networks because they promoted the shared values of responsibility (kuleana) and the need to care for (mālama) these landscapes. Such values and social networks are intrinsically linked to cultural ecosystem services (Pascua et al. 2017, Gould et al. 2019). These shared values were also engrained via the aforementioned sociocultural institutions.

\section{FORMS OF ECOMIMICRY INTEGRATED INTO HAWAIIAN SOCIAL-ECOLOGICAL SYSTEMS}

A key aspect of the ability of Hawaiian social-ecological systems to attain sustainable resource abundance ('äina momona; Gon et al. 2018, Kurashima et al. 2019) has been the development and integration of various forms of ecomimicry. In a prototypical Hawaiian social-ecological system, highly productive areas have been stabilized and expanded to facilitate the transformation of inorganic nutrients into organic carbon forms, or food for human consumption (conceptual model in Fig. 2). Careful management 
of these areas enhanced human benefits from ecosystem services, such as the abundance of multiple resource species, including those incorporated into the food system.

Fig. 2. A conceptual model of how the flow of fresh water (wavy, light-blue arrows), nutrients (light-green arrows with vertical lines), sediment (dotted brown arrow), phytoplankton (dark-green arrow with horizontal lines), and seawater (slim, wavy, dark-blue arrows) was managed in agroecology systems within a prototypical Hawaiian social-ecological system, juxtaposed with an aerial photograph of actual agroecology systems within a Hawaiian social-ecological system.

Ecomimicry practices managed abiotic resources to produce a sustainable abundance of food and other biocultural resources without degrading the health of adjacent coral reefs. (A) Water, in the form of rain and intercepted fog, is caught by forested mountains; (B) water, leached nutrients, and sediment flow into wetland agroecosystems that served as sediment retention basins and also produced food; (C) water and nutrients flow into aquaculture ponds that served as nutrient retention basins that produced food; (D) two-way water exchange between the pond and nearby coastal ocean enhance water quality and species management (via recruitment), also resulting in a healthy coral reef environment. (E) A 1928 aerial photograph of the ahupua'a of He'eia (Ko'olaupoko, O`ahu). Photo credit: unknown.

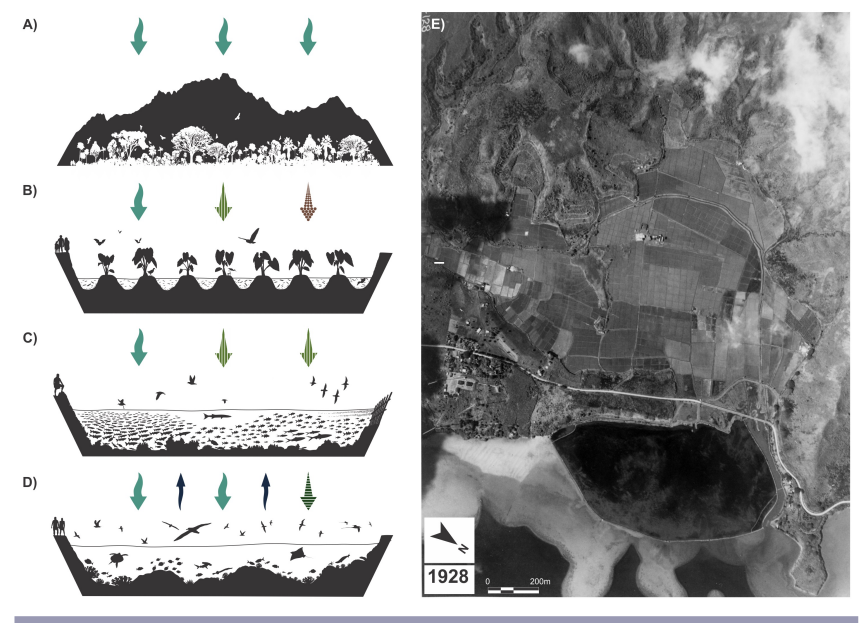

There are common threads in the approaches to ecomimicry practiced within Indigenous resource management systems, including Hawaiian social-ecological systems. In terrestrial environments, systems tended to be ecologically engineered to create heterogeneous environments on a landscape scale to maximize a diversity of habitats, which drove an increase in species richness on a localized scale through the management of ecological succession (Berkes 2018, Winter et al. 2018a). In aquatic environments, systems tended to be engineered to harness terrigenous nutrients and sunlight to fuel primary productivity at the base of the food web, and in turn supported an increased abundance of target species at higher trophic levels (Hiatt 1947b, DHM Inc. et al. 1990, Kikiloi 2003). Specific forms of ecomimicry employed in concert within Hawaiian social-ecological systems are explored below (Table 1). For the purposes of discussion, they have been categorized; however, these categories should not be considered mutually exclusive.

\section{Structural substitution}

Indigenous communities manage landscapes by augmenting species richness and abundance to increase the biocultural value of a particular area (e.g., Burnett et al. 2019). "Structural substitution" is a way of achieving this effect. This application of ecomimicry happens at the species level, whereby a species of certain structural niche is replaced with another species that fills a similar structural niche while maintaining the function of the system (e.g., replacing one mid-canopy species with another midcanopy species). It is a form of ecomimicry employed to induce a shift toward a desired species assemblage that maximizes targeted ecosystem services, including food production and biocultural value of landscapes. Structural substitution maintains the general habitat type but alters the species assemblage to increase specific ecosystem services intentionally while not decimating others (e.g., shifting the species assemblage of one forest type to another to increase cultural products while maintaining a forest habitat). In the context of Hawaiian socialecological systems, ecomimicry in the form of structural substitution is especially prevalant in two particular habitat types: forests and wetlands.

After human arrival in Hawai'i, conversion of prehuman ecosystems into Hawaiian social-ecological systems occurred through the habitat augmentation of forests and wetlands (Lincoln and Vitousek 2017, Gon et al. 2018, Winter et al. 2018a, $b$, Kurashima et al. 2019). However, by employing ecomimicry, Hawaiian management systems were able to retain most of the key functions and associated biodiversity of the native ecosystems in the process of enhancing those features desired by local communities. An example of structural substitution in forests is seen in integrated agroforestry practices, which created species assemblages that mixed the species brought as part of the Polynesian biocultural toolkit with highly useful native species (Lincoln and Ladefoged 2014, Winter and Lucas 2017). In the Kona region of Hawai' $i$ Island, where well-recorded agroecological zones were applied (Kelly 1983), we can see two different forms of structural substitutions in forests. In the 'apa' $a$ zone, which occurred in the rainforest belt, the native canopy was maintained but the subcanopy was altered. Here, the system was adapting to very poor soils; by maintaining the established forest canopy and the nutrient uplift, retention, and cycling associated with them, the understory species could thrive. In the kaulu ulu (breadfruit grove) zone, which occurred as a belt in the mesic midlands of the volcanic slopes (Lincoln and Ladefoged 2014), structural substitution almost completely converted the native mesic forest to a novel agroforestry system. Here, a mixed, open canopy dominated by 'ulu (breadfruit, or Artocarpus altilis) was established, along with other Polynesian-introduced trees of high biocultural value. The mid-canopy of this novel forest was occupied by various other Polynesian-introduced plants that could thrive in partial shade and allow the penetration of some sunlight to reach the forest floor for various crop species. Some native plants were maintained for medicinal and other biocultural traditions. As in other Pacific Island agroecology systems, these novel forest systems generally mimicked the multiple-tiered structure of native forests in which the canopy was dominated by one or two species with occasional additions, the subcanopy was more diverse with relatively dense cover, and dense groundcover species tended to occur in monotypic patches (Ticktin et al. 2018). This approach maximized nutrient, sunlight, and water usage. 
Table 1. Examples of various forms of ecomimicry integrated into the design of Hawaiian social-ecological systems in the precontact era, with descriptions of their management pathways and examples for each, along with a general list of associated ecosystem services. None of these forms persist today on a broad scale, but some forms are being revived on a local scale in remote pockets as the Hawaiian renaissance continues into its fourth decade.

\begin{tabular}{|c|c|c|c|}
\hline Ecomimicry type & Management pathway & Example system & Example ecosystem services \\
\hline $\begin{array}{l}\text { Structural } \\
\text { substitution }\end{array}$ & $\begin{array}{l}\text { Substituting out a nonedible species for } \\
\text { an edible one of similar structural } \\
\text { function; such a change in the species } \\
\text { assemblage of a given landscape increases } \\
\text { food production while maintaining a } \\
\text { similar structure and function to that of } \\
\text { the original habitat, including nutrient } \\
\text { cycling and water-use efficiency }\end{array}$ & $\begin{array}{l}\text { Multiple-tiered agroforestry to maximize } \\
\text { sunlight and space use, allowing for a diverse } \\
\text { species assemblage }\end{array}$ & $\begin{array}{l}\text { - Culturally relevant biodiversity } \\
\text { - Food production } \\
\text { - Nontimber forest products } \\
\text { - Nutrient cycling } \\
\text { - Mulch and fertilizer }\end{array}$ \\
\hline Habitat engineering & $\begin{array}{l}\text { Creating physical infrastructure and } \\
\text { engaging in associated management to } \\
\text { maintain a desired habitat type artificially }\end{array}$ & $\begin{array}{l}\text { Wetland agroecosystems that expanded wetland } \\
\text { habitat to integrate the cultivation of kalo (taro, } \\
\text { or Colocasia esculenta) with that of native } \\
\text { shellfish, fish, and waterfowl (Figs. } 2 \text { and 3) }\end{array}$ & $\begin{array}{l}\text { - Culturally relevant biodiversity } \\
\text { - Food production } \\
\text { - Other biocultural traditions } \\
\text { - Sediment retention } \\
\text { - Aquifer recharge } \\
\text { - Water quality }\end{array}$ \\
\hline $\begin{array}{l}\text { Habitat } \\
\text { augmentation }\end{array}$ & $\begin{array}{l}\text { Mounding and aligning stones to create } \\
\text { lithic features within a climatic, nutrient, } \\
\text { and/or habitat context to maximize } \\
\text { ecosystem services and/or minimize } \\
\text { ecosystem disservices }\end{array}$ & $\begin{array}{l}\text { Lithic berms using microtopographic climate } \\
\text { design (kuaiwi) in intensified rain-fed agriculture } \\
\text { (Fig. 4) }\end{array}$ & $\begin{array}{l}\text { - Topsoil stabilization } \\
\text { - Moisture retention } \\
\text { - Focused nutrient leaching }\end{array}$ \\
\hline $\begin{array}{l}\text { Habitat } \\
\text { enhancement }\end{array}$ & $\begin{array}{l}\text { Managing a habitat or its surroundings to } \\
\text { enhance productivity by altering the } \\
\text { limiting abiotic factors }\end{array}$ & $\begin{array}{l}\text { Increasing light inputs to nutrient-rich streams } \\
\text { to generate higher levels of primary productivity }\end{array}$ & $\begin{array}{l}\text { - Increased food production } \\
\text { (invertebrates and fish) }\end{array}$ \\
\hline $\begin{array}{l}\text { Induced } \\
\text { disturbance for } \\
\text { succession } \\
\text { management }\end{array}$ & $\begin{array}{l}\text { Imposing disturbance regimes that } \\
\text { enhance habitat diversity, biological } \\
\text { turnover, and nutrient pulses to promote } \\
\text { primary productivity and successional } \\
\text { species }\end{array}$ & $\begin{array}{l}\text { Shifting agriculture with novel forest systems } \\
\text { that created light gaps and nutrient pulses to } \\
\text { facilitate a successional series of agriculture }\end{array}$ & $\begin{array}{l}\text { - Enhanced primary productivity and } \\
\text { nutrient cycling } \\
\text { - Enhanced assemblage diversity } \\
\text { - Culturally relevant biodiversity } \\
\text { - Food production } \\
\text { - Timber and nontimber forest } \\
\text { products }\end{array}$ \\
\hline Trophic engineering & $\begin{array}{l}\text { Managing nutrient flows to favor trophic } \\
\text { transfer efficiency }\end{array}$ & $\begin{array}{l}\text { Aquaculture ponds that increased primary } \\
\text { production and enhanced the trophic food web, } \\
\text { which led to an increase in the abundance of } \\
\text { native shellfish and fish species }\end{array}$ & $\begin{array}{l}\text { - Food production } \\
\text { - Efficient nutrient cycling } \\
\text { - Shoreline stabilization }\end{array}$ \\
\hline $\begin{array}{l}\text { Trophic } \\
\text { management and } \\
\text { fecundity } \\
\text { management }\end{array}$ & $\begin{array}{l}\text { Selective reduction or protection of } \\
\text { species at specific trophic levels to } \\
\text { promote a desired ratio in the ecosystem }\end{array}$ & $\begin{array}{l}\text { Focused fishing of predatory fish during the } \\
\text { spawning period of resource fish at lower } \\
\text { trophic levels }\end{array}$ & $\begin{array}{l}\text { - Species abundance of key resource } \\
\text { fish } \\
\text { - Food production (protein) } \\
\text { - Product of agricultural surplus }\end{array}$ \\
\hline
\end{tabular}

The creation of this novel forest in the lowland areas ensured that the forests closest to human habitations provided increased production such as food, timber, and nontimber forest products while maintaining critical ecosystem services such as flood and erosion control (Quintus et al. 2019). An example of structural substitution in wetlands is seen in wetland agroecology, which maintained the structure and function of wetlands while increasing food production. Nonedible wetland sedges were substituted with kalo (taro, or Colocasia esculenta), which filled the same structural niche in the system; its cultivation maintained wetland habitat for native waterbirds, fishes, and invertebrates that were also food sources.

The social-ecological zones included in the Hawaiian resource management system (i.e., the moku system) created certain zones that were designated as appropriate for various forms of ecomimicry and others that were designated as inappropriate for any ecomimicry practices (e.g., wao akua, "sacred forest" areas). This approach ensured that augmented species assemblages did not fully displace native species assemblages, which themselves provided desired ecosystem services (Winter and Lucas 2017, Winter et al. 2018a; Fig. 1).

\section{Habitat engineering}

Habitat engineering converts a habitat from its original spatial extent, which could be limited, fragmented, and fluctuating, into a spatially expanded and continuous state that favors a desired species assemblage. In Hawaiian social-ecological systems, habitat engineering took various forms, including, but not limited to, wetland agroecology in terrestrial environments that converted forests in alluvial plains to wetland agroecosystems.

Wetland agroecology is a form of ecomimicry that exists throughout the Pacific and Southeast Asia (Berkes 2018). It was adapted to taro cultivation in Polynesia and then transported to and further adapted in Hawaiian social-ecological systems. It involved landscape engineering in terrestrial areas adjacent to lotic systems, which included riparian areas, wetlands, and alluvial plains. Through a system of irrigation ditches and terraced ponds, water was diverted out of streams and spread across the landscape. 
The ultimate purpose of wetland agroecology was to provide habitat for a particular species assemblage focused around the cultivation of kalo that included native waterfowl, fish, invertebrates, and other plants (Figs. 2B and 3; Handy et al. 1972), all of which were important food sources. This engineering expanded their habitat and drove an increase in their populations (i.e., species abundance; Winter et al. 2018a,b). Paleoecological data indicate that some species of endemic birds (e.g., the waterbird 'alae ' ula, or Gallinula galeata sandvicensis; and the owl pueo, or Asio flammeus sandwichensis) do not appear in the fossil record until after the development of Hawaiian social-ecological systems increased their habitat area and hence their population size (Burney et al. 2001, Burney and Kikuchi 2006). Culturally important plants such as native sedges for weaving and cordage also thrived in these wetland habitats (Abbott 1992).

This engineering mimicked prehuman wetlands and harnessed the associated ecosystem services: trapping sediment and slowing water associated with storm events, processing nutrients from terrestrial sources, and facilitating increases in groundwater recharge (Maltby and Acreman 2011). This patchwork design of wetland pond fields accomplished these goals by effectively creating sediment retention basins, which played a large role in flood control and helped to retain eroded topsoil and leached nutrients within the landscape, which was especially valuable during storm events (Koshiba et al. 2013, Bremer et al. 2018), and therefore minimized sediment entering adjacent coastal waters and smothering reef habitats (Figs. 2B and 3). This design also supported groundwater recharge by slowing the rate of water flow out of the watershed, which can be extreme in tropical high-island systems, and expanding the surface area over which it flowed. Wetland agroecosystems also mimicked ecosystem processes such as disturbance regimes by creating a shifting mosaic of disturbance patches, including unflooded fallow patches (Fig. 3) as described by Nakamura et al. (2000). An example of this strategy can be seen in the stories associated with the Hawaiian proverb from the moku of Kona on the island of Kaua i, "Mānā, i ka pu'e kalo ho'one'ene'e a ka wai." This phrase translates to, "Mānā, where the mounded taro moves in the water,"(Pukui 1983) and documents early innovations in agroecology whereby kalo was grown in rafts to deal with fluctuating water levels. As such, this agroecological design used natural disturbance regimes (e.g., floods) to its advantage, thereby increasing the resilience of both ecosystem service provisioning and the human community that depended upon those services in the face of storm events.

Wetland agroecosystems have been described as a keystone component of some Hawaiian social-ecological systems because they shaped a complex sociocultural system and influenced biocultural resource management on a landscape scale (Winter et al. 2018b). As with other agroecological production methods around the world (Altieri 1999, 2004, Jarvis et al. 2008), traditional kalo fields were not monocultures, but rather constituted complex agroecosystems capable of sustaining high levels of food production and both intra- and interspecific biodiversity (Winter 2012, Winter et al. 2018b). Kalo was a structural substitute for native sedges, and its cultivation provided habitat for native wetland animals (e.g., waterbirds, fish, and invertebrates), many of which were also food resources. Therefore, this form of ecomimicry stabilized and expanded the provisioning of ecosystem services from wetland habitats for the cultivation of complex carbohydrates while expanding habitat for native species that were also important resources. It subsequently provided increases in food abundance and food security while retaining water and sediment. However, as with other forms of intensified agriculture, proper management was needed to avoid detrimental increases in nutrient loads downstream and in the estuary (Bremer et al. 2018). This potential ecosystem disservice actually created an opportunity to design and develop other forms of ecomimicry as mitigation measures downstream (e.g., aquaculture ponds, see Forms of ecomimicry integrated into Hawaiian social-ecological systems: Trophic engineering).

Fig. 3. A 2019 photograph of the heterogeneous landscape created by a wetland agroecosystem in the ahupua $a$ of Hanalei on Kaua i Island. Photo credit: Kawika B. Winter.

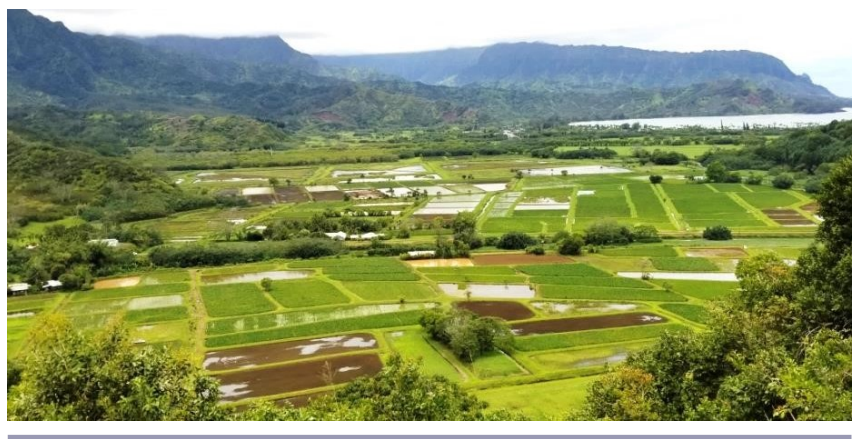

\section{Habitat augmentation}

Habitat augmentation is the application of topographical alteration that alters the microclimatic patterning of a habitat without completely changing the habitat form or function. One example is the alignment and/or mounding of native stones in an area to create lithic features that increase productivity around them. Within Hawaiian social-ecological systems, large-scale agroecosystems in more marginal habitats were built around the intensified cultivation of 'uala (sweet potato, or Ipomoea batatas) in rain-fed systems (Kirch et al. 2005, Kagawa and Vitousek 2012). Habitat augmentation was applied extensively within these systems. Specifically, microtopographical features such as lithic mounds and linear embankments (kuaiwi) were built across the landscape. In some cases, habitat augmentation was widespread and relatively uniform, such as in the leeward Kohala agricultural systems where extensive berms blanketed approximately $60 \mathrm{~km}^{2}$ (Fig. 4; Ladefoged et al. 2011, 2018). There, the habitat augmentation appears to be in response to large-scale weather patterns. In the case of leeward Kohala, consistent trade winds are amplified in the channel between Hawai' $i$ and Maui islands, resulting in extreme winds that greatly enhance evapotranspiration (Kagawa-Viviani et al. 2018) but also have high levels of mist and moisture. The microtopographic installations created perturbations to the wind, creating a minute island effect of windward and leeward mist deposition that both brought water into the system and redistributed water within the system (Lincoln et al. 2017, Marshall et al. 2017). The hydrological effect of these walls resulted in more reliable food production, enhancing the resilience of the system (Kagawa and Vitousek 2012). Additionally, the walls appear to be used in terms of lithic mulch that mimicked rock outcroppings, which naturally enhanced soil fertility 
(Ladefoged et al. 2010). Alternatively, in the moku of Kaupō on Maui Island, more specific habitat augmentation occurs within microhabitats (Kirch et al. 2004, 2005, 2009, 2013). The habitat augmentation appears to have been in response to a range of factors, using a host of landscape alterations to affect the movement of soil, water, and nutrients through the system. A hydrological example of several microsites shows that finegrained ash acts as a moderately impervious aquifer but is covered by a thick layer of highly porous cinder. The cinder prevents the capillary rising of water from the ash layer, and the roots of most modern plants rarely penetrate the coarse dry cinder to reach the abundance of water in the buried layer of fine tephra. The ancient Hawaiian gardeners exploited these features through habitat augmentation by breaking through the cinder layer and planting within the created depressions (Kirch et al. 2005). Evidence suggests that these applications of ecomimicry facilitated the expansion of human populations into drier areas than would otherwise be possible in social-ecological systems designed around the cultivation of kalo (Lincoln et al. 2017, 2018).

Fig. 4. The archaeological remains of a lithic berm (kuaiwi) in Kealakekua, Kona Hema, Hawai i. Such lithic berms were constructed to increase ecosystem services (e.g., moisture retention) and decrease ecosystem disservices (e.g., erosion) in intensified rain-fed agroecology. Photo by N. K. Lincoln.

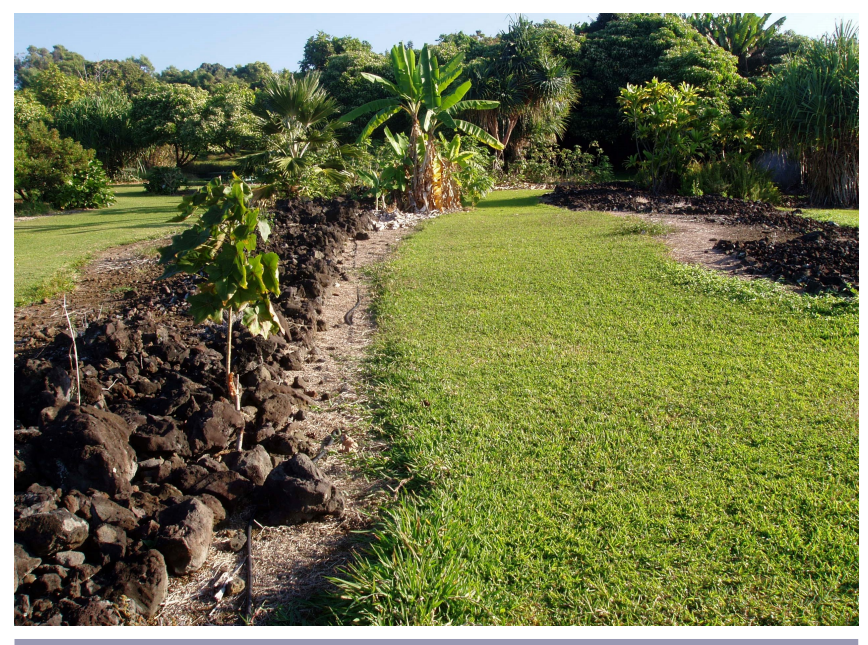

An example of habitat augmentation in aquatic systems is the construction of fish houses (imu or $a h u$ ) in shallow nearshore areas (Maly and Maly 2003b, Kahaulelio and Pukui 2006), which added structural complexity in nearshore environments and essentially equated to miniature artificial reefs along the coastline. Hawaiian nearshore habitats are characterized by high wave energy and low habitat complexity relative to other locations throughout the Pacific (Bird et al. 2013, Franklin et al. 2013). Therefore, the habitat complexity with high rugosity (created by large areas of coral reefs) that does exist is an important driver of coral reef biodiversity and abundance (Friedlander and Parrish 1998, Rodgers et al. 2010). Imulahu construction thereby mimicked the structurally complex coral reef to create habitats for cryptic species and safe-zone habitats for juvenile fishes (Madin et al. 2019), all of which are necessary for healthy ecosystem functioning. Fish houses were typically constructed between the low-tide mark and the coral reef, particularly in sandy or boulder-strewn areas, where wave activity diminishes structural complexity (Maly and Maly 2003b). These structures could be disassembled and reconstructed as needed in conjunction with surround nets to catch fish that colonized the constructed habitat. These fish houses were relatively small, being hollow stackings of rocks approximately $1 \mathrm{~m}^{2}$ in size, and were not nearly as productive as aquaculture technologies, but they once dotted the coastline in areas that would support these structures. This practice of ecomimicry resulted in a cumulative increase in safe-zone habitat for reef fish (juveniles in particular), driving an increase in their population abundance along the shoreline. Some fish were caught and eaten by people, whereas others colonized the coral reef and contributed to maintaining robust populations of reproductive adult reef fish. This method of ecomimicry primarily facilitated the harvest of immature herbivores and was mainly reserved for elders who no longer had the responsibility of feeding a large family and who had limited physical ability and reduced dietary needs associated with the aging process. This practice facilitated the ability of elders to maintain their independence, and it ensured that a key demographic in the population had an identified food source. Norms and expectations within the sociocultural system directed younger, stronger fishers to conduct their fishing activities in the coral reefs or in the open ocean (Maly and Maly 2003b). This expectation likely also limited the widespread harvest of juveniles, ensuring that many could enter the reproductive population, which ultimately contributed to greater abundance of these species on nearby reefs.

\section{Habitat enhancement}

Habitat enhancement is the physical manipulation of native habitat to increase its productivity. A key habitat in Hawaiian social-ecological systems that was enhanced were streams. Streams were particularly important when the ocean was too rough for fishing, or when sociocultural events such as a wedding or a funeral called for the feeding of a large gathering of people (Kimura and Mahuiki 1975, Maly and Maly 2003a). Such intermittent reliance on stream resources was another mechanism to relieve harvesting pressure on other systems such as coral reefs. This redundancy provided resilience in the food system.

Habitat enhancement in streams involved two processes: managing canopy trees in the riparian corridor to maximize the level of sunlight hitting the stream, driving an increase in primary productivity within the water; and using practices to maintain the integrity of stream health. Prior to human habitation (and in unmanaged areas today), the generally narrow and steep-sided streams were covered by a closed canopy of trees from both sides of the stream. However, in Hawaiian management systems, canopy trees were cleared from alongside all stream banks to minimize debris-fall and to maximize the amount of sunlight entering the stream, while leaving other woody vegitation in place to maintain the stability of the riparian area. This practice not only increased the suitability of this habitat for human interaction, but also enhanced the primary productivity of the streams, which were previously limited in their productivity by the light-limiting forest canopy (Vitousek et al. 2010). In addition, flow rates, riffles, and pools were managed to maintain optimum temperature and oxygenation for native vertebrates and invertebrates to thrive, especially within the wetland agroecological system (Maly and Maly 2003a). A complex myriad 
of rules and regulations relating to water conservation (e.g., kapu and kānāwai) were developed within Hawaiian social-ecological systems and helped to achieve these goals for a robust human population in the precontact era (Kamakau et al. 1964, Handy et al. 1972, Kamakau 1976, Maly and Maly 2003b).

Key among these rules was the strict prohibition against urinating and defecating in or around any water sources (e.g., springs, streams, and irrigation ditches), borne from the understanding that human waste transported by water is an ecosystem disservice. This rule meant that the main approach to human waste management systems was via dry (no-flush) pit latrines (lua) coupled with a requirement for their placement far away from sources of fresh water. Another key restriction forbade the diversion of $>50 \%$ of the water out of streams for the purposes of wetland agroecology (Nakuina 2007, Sproat 2015). There was also a broad mandate to ensure there were no blockages impeding the flow of water anywhere in the system (e.g., springs, streams, and irrigation ditches). Philosophies and religious ideals, which were strengthened by sociocultural institutions, helped to ensure community adherence to the rules and regulations that were designed to protect the integrity of fresh water sources (Kurashima et al. 2018). These ideals, along with threat of swift and severe punishment, minimized the need for enforcement actions against noncompliant individuals (Sproat 2015).

\section{Induced disturbance for succession management}

Induced disturbance for succession management creates a controlled disturbance regime to harnesses the products of multiple successional stages simultaneously in a local setting. Disturbance, edge effects, and succession result in the production of a diversity of ecosystem services and biocultural products (Turner et al. 2003). Such concepts were leveraged in the management of Hawaiian agroecosystems. Furthermore, the application of such strategies appears to have been directly adapted to the ecological potential of areas to sustain the enhanced productivity that accompanies disturbance and succession regimes.

The best documented example of induced disturbance for succession management is a system of shifting cultivation known as the pākukui method, which was practiced in the moku of Hāmākua on Hawai'i Island (Lincoln 2020). A novel forest of kukui (Aleurites moluccanus), a fast-growing tree species, was primarily established explicitly for the accumulation of nutrients. Within this moku, shifting (i.e., swidden) agriculture was practiced in which areas of trees were felled, composted, and planted with kalo. The word pākukui literally means "kukui plot" but metaphorically means "vagabond" in reference to the wandering, as opposed to sedentary, nature of kalo cultivation through the forest (Pukui and Elbert 1986). Although shifting cultivation is common in many traditional agricultural systems, what makes the pākukui particularly fascinating, and an example of applied ecomimicry, is that the spatial extent of this practice related very strongly to underlying factors driving soil fertility (Lincoln 2020). This practice of shifting cultivation in precontact Hawai $i$ appears to have only occupied a limited niche of moderate soil fertility. More fertile areas were developed for more intensive cultivation of annual and perennial crops, whereas areas of lower fertility were devoted to the development of permanent novel agroforests (i.e., structural substitution as described earlier). The intelligent design and landscape-level shift of strategies suggests intentional and informed application of ecomimicry relating to environmental opportunities and constraints.

Another example of successional management is the creation of landscape mosaics such as patches of highly tended forests to augment cumulative ecosystem services on a landscape scale. Incorporating forests into mosaicked landscapes is a common form of ecomimicry in Indigenous social-ecological systems (Robson and Berkes 2011, Berkes 2018) and is documented throughout Polynesia, including Hawai'i (Lincoln and Vitousek 2017, Quintus et al. 2019). This approach mimics succession and other ecological processes to create heterogeneity and drive an increase in the ecosystem services that forests can provide (Robbins et al. 2015, Ticktin et al. 2018). Hawai i provides examples of old-growth forest patches within the broader agricultural landscape. Such a mosaic produced edge effects within the forest habitat, which resulted in a myriad of ecological benefits to the agroecosystems surrounding old-growth patches, including providing shade, nutrient uplift, microhabitats, and wildlife habitat, all of which enhanced productivity while maintaining greater landscape-level biodiversity than either forest or agriculture could provide alone.

\section{Trophic engineering}

Trophic engineering is the engineering of systems to manage food webs. We build on the work of Sanders et al. (2014) to describe trophic engineering as a form of ecomimicry that focuses on the nodes and links of food chains to influence food web structure and dynamics. In this sense, we use the term "food-chain reaction" to describe the process of increasing the abundance of lower trophic-level components to drive an increase in abundance of a target species at higher trophic levels.

In Hawaiian social-ecological systems, trophic engineering focused on aquatic primary production of micro- and macroalgae, which is a foundational ecosystem service. Not only was macroalgae (limu) an important component of the Indigenous food diet (Abbott 1996, Winter et al. 2018a), but algal production in general is foundational to food web productivity in nearshore environments (Barnes and Hughes 1999). This approach was applied in Hawaiian social-ecological systems via aquaculture ponds (i.e., fishponds, or loko $i^{i} a$ ) to enhance trophic transfer efficiency by increasing primary productivity in aquatic environments in the lowlands and coastal areas.

Lands with aquaculture ponds were noted as places of sustainable abundance ('äina momona; Kamakau 1976) because algal production through engineered aquaculture ponds drove an increase in the abundance of fish biomass (i.e., fish stocks). Engineered aquaculture ponds fall into four main classes that were integrated into Hawaiian social-ecological systems in both freshwater and brackish water habitats (Summers 1964, Handy et al. 1972, Kamakau 1976, Kikuchi 1976, Maly and Maly 2003b; Table 2). These ponds created environments to favor fish that thrived on microalgae (e.g., phytoplankton, including diatoms), macroalgae, and invertebrates (Hiatt 1947a,b). This application of trophic engineering mimicked ecosystem processes to take advantage of native biodiversity, spatiotemporal variability, and the unique geomorphology of Hawaiian wetlands and coastal landscapes. This engineering led to increased productivity of those key resource species. The design of one class of aquaculture 
in particular (loko kuapā; Table 2, Fig. 2C, bottom of Fig. 2E) was based on the highly productive nature of estuaries and their ecological function as a nursery area for juvenile fish and invertebrates. Given the lack of brackish water aquaculture ponds elsewhere in the Pacific, these ponds can be considered novel innovations of ecomimicry developed in Hawai'i.

Table 2. The classes of aquaculture technologies (loko) developed in Hawaiian social-ecological systems to increase the abundance of key resource species. Compiled from Maly and Maly (2003b).

\begin{tabular}{|c|c|c|c|}
\hline $\begin{array}{l}\text { Aquacult- } \\
\text { ure class }\end{array}$ & Description & Size & Function \\
\hline loko wai & $\begin{array}{l}\text { A freshwater } \\
\text { type used inland } \\
\text { from the coast }\end{array}$ & $\begin{array}{l}\text { Small }\left(\mathrm{a} \text { few } \mathrm{m}^{2}\right) \text { to } \\
\text { relatively large } \\
\left(20,000 \mathrm{~m}^{2}\right)\end{array}$ & $\begin{array}{l}\text { Relatively deep } \\
\text { ponds }(>1 \mathrm{~m}) \text { used } \\
\text { to raise fish and } \\
\text { waterbirds }\end{array}$ \\
\hline loko kalo & $\begin{array}{l}\text { A freshwater } \\
\text { type used inland } \\
\text { from the coast }\end{array}$ & $\begin{array}{l}\text { Small }\left(\mathrm{a} \text { few } \mathrm{m}^{2}\right) \text { to } \\
\text { relatively large } \\
\left(20,000 \mathrm{~m}^{2}\right)\end{array}$ & $\begin{array}{l}\text { Medium-depth }(\sim 1 \\
\text { m) ponds shallow } \\
\text { enough to grow kalo } \\
\text { in mounds, yet deep } \\
\text { enough for fish to } \\
\text { survive; also } \\
\text { designed to raise } \\
\text { waterbirds }\end{array}$ \\
\hline $\begin{array}{l}\text { loko } \\
\text { pu'uone }\end{array}$ & $\begin{array}{l}\text { A brackish water } \\
\text { type used within } \\
\text { dune complexes } \\
\text { along the coast }\end{array}$ & $\begin{array}{l}\text { Relatively small, } \\
\text { usually }<2 \mathrm{~km}^{2}\end{array}$ & $\begin{array}{l}\text { Designed primarily } \\
\text { to raise fish }\end{array}$ \\
\hline $\begin{array}{l}\text { loko } \\
\text { kuapā }\end{array}$ & $\begin{array}{l}\text { A brackish water } \\
\text { type built as } \\
\text { walled ponds in } \\
\text { estuaries along } \\
\text { the coast (Fig. 5) }\end{array}$ & $\begin{array}{l}\text { The largest class of } \\
\text { aquaculture pond; } \\
\text { most were }>0.01 \\
\mathrm{~km}^{2} \text {, with the largest } \\
\text { documented one at } \\
2.4 \mathrm{~km}^{2}\end{array}$ & $\begin{array}{l}\text { Designed primarily } \\
\text { to raise fish, but } \\
\text { because of their size } \\
\text { and depth, can host } \\
\text { a broad array of } \\
\text { vertebrates and } \\
\text { invertebrates }\end{array}$ \\
\hline
\end{tabular}

In terms of their physical and biogeochemical functions, Hawaiian aquaculture ponds essentially drove an increase in primary productivity at the base of the prehuman aquatic food web by harnessing nutrients flowing through the watershed along with available sunlight and managing abiotic characteristics of the water (discussed below). These systems were engineered to be large, semi-enclosed mesocosms that trapped nutrified water and controlled its residence time to facilitate beneficial blooms of benthic algae and phytoplankton. Diatom production was particularly important (Hiatt 1947b) and was accomplished by maximizing the temporal abundance and minimizing the uncertainty of these "bloom-and-bust" taxa (Gross 2012). Thus, through trophic engineering, these technologies conceptually mimicked natural blooming conditions (e.g., oceanic eddies; Brown et al. 2008, Rii et al. 2008) to create "phytoplankton incubators" (Fig. 2C, bottom of Fig. 2E) that induced a foodchain reaction that resulted in increased stocks of herbivorous fish and invertebrate-consuming piscivores. Some examples include increased 'ama'ama (striped mullet, or Mugil cephalus) stocks through the consumption of increased micro- and macroalgae production, and increased moi (Pacific threadfin, or Eleutheronema tetradactylum) stocks through consumption of increased production of secondary consumers (e.g., micro- and macroinvertebrates; Fig. 2; Hiatt 1947a,b, Adolf et al. 2019). This food-chain reaction ultimately supported higher fish stocks than would be possible in an unmanaged system (Costa-Pierce 2008).
Within coastal aquaculture systems, sluice gates were used in conjunction with daily tidal fluxes to manage salinity, temperature, dissolved oxygen, flushing rates, and residence time of water in the pond (McCoy et al. 2017, Möhlenkamp et al. 2019). Conceptually, the incorporation of sluice gates into the design of walled ponds, purposely placed in directions favorable to currents in the area, was key to maintaining maximum production of desired fish species. Proper management allowed for an influx of seawater that renewed inputs of low-nutrient water and seed populations of desired phytoplankton assemblages (smaller eukaryotes and cyanobacteria, as well as diatoms) to maintain a food-chain reaction that resulted in increased fish stocks. This deliberately orchestrated succession pattern prevented an inundation of organic matter production and uncoupled remineralization (e.g., nutrient recycling) of organic products, which could result in a stunted microbial loop. Sluice gate control also allowed for wild recruitment of pua (juvenile fish) to enter the pond to serve as seed populations for the species assemblage needed to maintain the food-chain reaction.

The nutrients needed to sustain beneficial algal blooms within the confines of aquaculture ponds were harnessed from two sources: submarine groundwater discharge (SGD) and run-off from wetland agroecosystems. In Hawai i, SGD naturally acquires high levels of inorganic nitrogen and other micronutrients from dissolution of basaltic rock. Groundwater springs and seeps prevalent along the coastline contribute to primary production in aquatic environments (Doty and Oguri 1956, Duarte et al. 2010, Amato et al. 2016, Gove et al. 2016). Some researchers have hypothesized that coral rubble embedded within the kuapa (pond walls), or the sand dunes themselves in pu'uone-class ponds, may have regulated dissolved inorganic carbon concentrations and associated $\mathrm{pH}$ within the ponds. Conceptually, inorganic nutrients concentrated in the fishpond allow diatoms to multiply rapidly, which facilitated efficient transfer of energy in carbon form through the fishpond food web, thereby maximizing trophic transfer efficiency. This efficiency could have started the foodchain reactions that resulted in an abundance of higher trophic organisms.

Aquaculture ponds not only drove increases in ecosystem services, they also mitigated ecosystem disservices such as those associated with intensified agriculture. Intensified agriculture such as wetland agroecology can enrich water with nutrients beyond baseline levels (Bremer et al. 2018), and it also affects the chemistry of SGD (Welch et al. 2019). Without sinks to mitigate eutrophication, agricultural run-off can result in ecosystem disservices by fueling harmful blooms of undesirable phytoplankton and macroalgae in nearby coastal waters; in the worst case scenario, such blooms create hypoxic conditions that lead to fish deaths (Smith et al. 2002, Dailer et al. 2012, McCoy et al. 2017). Instead, aquaculture infrastructure throughout the wetland system and at the terminus of the watershed provided an ecosystem service by mitigating the flux of nutrients from intensified agriculture into ponds to facilitate fish farming. The pulsing pattern of flushing water through the sluice gates (on outgoing tides) in coastal ponds prevented elevated nutrients and phytoplankton blooms from overwhelming coral reefs and becoming an ecosystem disservice. To the contrary, the pulsed flushing managed blooms as an ecosystem service to provide available plankton (e.g., zooplankton and other secondary consumers) outside the fishpond and contribute toward building 
a trophic foundation of a healthy coral reef food web. In such ways, Hawaiian aquaculture infrastructure was designed to mimic and take advantage of the important exchange between land-sea interactions while enhancing fish stocks and protecting the nearshore coral reefs from ecosystem disservices. This infrastructure was specifically designed to result in an increase in the abundance of targeted fish species in the system. Recent research into the health and productivity of nearshore coral reefs in the Hawaiian era (Kittinger et al. 2011, Bahr et al. 2015) supports this function as having been effective.

\section{Trophic management and fecundity management}

Trophic management is the manipulation of food webs outside of engineered infrastructure to increase the abundance of key resource species. It is built on an understanding of trophic ecology that manages nutrient delivery from land to manipulate aquatic primary productivity and drive an increase in fish biomass in nearshore marine environments (i.e., bottom-up control). In fishponds, trophic management traditionally emphasized the productivity of herbivorous fishes through enhanced nutrient delivery to increase both micro- and macroalgal growth (Hiatt 1947a). Furthermore, predation on herbivorous fish was diminished by focused culling and consumption of piscivorous fish. Because energy transfer between trophic levels is generally inefficient, herbivorous fish maintain greater biomass and are more abundant than piscivorous fish (Lindeman 1942, Hiatt 1947b). Reliance on herbivores and other lower trophic level components of the food web provides a more efficient and sustainable strategy for maintaining a consistent abundance of food sources from aquatic environments.

There were five major classes of harvest restrictions (kapu) implemented in the moku system to manage population dynamics for species abundance (Winter et al. 2018a). One class, tied to fecundity management, was intended to maximize the reproductive output of key resource species. To enhance fecundity, restrictions were placed on key resource fish during their spawning season (Colding and Folke 2001, Friedlander at al. 2002, Poepoe et al. 2003). Knowledge about the seasonality and timing of spawning for various species and how they are correlated with the phenology of other species was encoded in proverbs (Pukui 1983). An example of a proverb that encapsulates both trophic management and fecundity management can be seen in the stories associated with the Hawaiian proverb from Kona Hema (South Kona), "hānai a "ai", which roughly translates to "feed [the fish], and [you may] eat" (Maly and Maly 2003b, Winter et al. 2018a, Chang et al. 2019b). This proverb refers to an annual fishing restriction on 'opelu (Decapterus macarellus) that corresponded with the practice of fish feeding, using excess carbohydrate sources cultivated on the land, during their spawning season to drive an increase in fecundity. As part of this practice, there was a specific restriction against using meat to feed fish because it would attract predators of the fish that were being fed (Maly and Maly 2003b). Concurrent with this fishing restriction on key lower trophic level resource fish (e.g., 'opelu) during their spawning season was a shifted reliance from coral reefs to pelagic predator species as food sources (e.g., $a k u$, or Katsuwonus pelamis). Coupled approaches to trophic management and fecundity management likely drove an increase in species abundance initially and then maintained that abundance of key resource species in and around coral reefs
(Kittinger et al. 2011). This practice also ensured diversified sources of fish protein. Beyond that, a complex system of regulations ( $k a p u$ ) was designed to manage population dynamics and species connectivity to ensure robust and healthy populations of a diverse array of resource species. These rules were meant to ensure that coral reefs could remain the source of several types of resource species for food throughout seasons and across generations (Winter et al. 2018a).

\section{CONCLUSIONS AND FUTURE RESEARCH}

This contribution brings together explorations of various discplines into the design, structure, and function of Hawaiian social-ecological systems to analyze them under an ecological lens and house them under the umbrella concept of an adaptive ecosystem-based management strategy termed ecomimicry. This conceptualization provides an opportunity to examine the ecological underpinnings of Indigenous resource management systems. These management systems helped to maintain diversity, as well as ecosystem function and services. They served to minimize uncertainty of resource availability while maintaining system resilience. Novel terms were developed during this process to classify common forms of ecomimicry seen throughout Indigenous resource management systems generally, and in Hawaiian social-ecological systems specifically. The actual application of these terms is broader than the limited examples explored here.

The concept of ecomimicry provides an alternate narrative to the premise that human presence and actions are inherently destructive to nature and ecological processes. In reality, humanity has a long history of employing ecomimicry to ensure sustainable resource use. Indigenous communities that have the longest histories and relationships with a particular place and its native biodiversity provide the ideal setting to investigate such approaches. The genius of the Hawaiian resource management system was that although the relative proportions of habitats were altered in the precontact period (for example, increased proportion of wetland vs. forest in the system), there is no evidence to suggest that any habitats were eliminated or destroyed. There is ample evidence, however, that the use of a variety of ecomimicry schema in concert on the landscape drove an increase in species richness and abundance, which in turn sustainably supported a thriving human population.

Based on our synthesis, ecomimicry was used in Hawaiian socialecological systems to manage water, nutrients, sediments, and biodiversity to achieve and maintain a sustainable stable-state of resource abundance ('äina momona). This system was resilient because it was founded on the management of disturbance regimes. Within that context we suggest there is a fundamental formula for successfully incorporating forms of ecomimicry into the design and management of a social-ecological system: (1) identify a suite of key resource species and what they need in terms of habitat and nourishment (biotic or abiotic resources), (2) integrate those needs into the structure of the social-ecological system, (3) nourish those resource species with a by-product or an under-used component of another part of the overall system, (4) provide protection for those species during their reproductive periods and regulate the harvest to maximize their fecundity, and (5) strengthen cultural norms via sociocultural institutions and organizations that reinforce a stewardship ethic to minimize the risk of overharvest. 
This formula can drive an increase in the abundance of resource species and allow the social-ecological system to harness and increase key ecosystem services as part of its core function. Although there are many nuances, this general approach to conceptualization provides some common language for people from different disciplinary backgrounds and worldviews to have conversations about sustainability solutions in the Anthropocene. Incorporating such conceptualizations into the design of communities, cities, and resource management policies can promote opportunities for humans to engage and connect with their place through stewardship projects and sustainable behavior. Hawaiian social-ecological systems are examples of how this approach may be accomplished, and they provide lenses with which we can examine how ecomimicry can be incorporated into the design and management of social-ecological systems to optimize the productivity of key habitats. In the approaches designed for Hawaiian social-ecological systems, particular habitats were generally managed for food abundance and for resilience by maintaining flexibility and keeping options open. This dual-purpose approach created storm-resilient systems that harnessed the nutrient run-off associated with intensified agriculture to drive a higher abundance of invertebrates, fish, and waterfowl than without direct human management. Thus, ecomimicry provided food security while mitigating the unavoidable outputs of intensive agriculture. This approach also helped drive a cumulative net increase in the quality and quantity of key ecosystem services, including species richness and abundance, drinkable water, aquifer recharge, sediment retention, nutrification, and biocultural diversity, as well as health and wellness in families and communities. Such was the foundation of sustainable abundance ('âina momona) within Hawaiian socialecological systems.

In the process of understanding how ecomimicry can lead to sustainable abundance, we can shift the narrative from "humans are the problem" to a paradigm that instead identifies particular behaviors as the problem and embraces the virtues of humanity as the solution. However, a detailed understanding of the keys to long-term success still eludes us. Research into the nuances of the concepts explored herein is needed to elucidate how the various forms of ecomimicry function at a fundamental level in Hawaiian social-ecological systems. Areas for research include, but are not limited to: heterogeneous landscape design, agroecology, habitat engineering, habitat augmentation, habitat enhancement, structural substitution, controlled disturbance and succession, trophic engineering, trophic management, and fecundity management.

Metrics for assessing environmental health and ecosystem services, as well as measures of human health and well-being across the scale of extended families and communities, are also needed. Policy-oriented applied research can help reveal how these biocultural systems can be restored and adapted to conditions that currently exist in Hawai i, especially in the context of the global climate crisis, invasive species, urbanization, and the dominant economic and governance systems. Such research should incorporate the role of culture in restoring the health and function of Hawaiian social-ecological systems, at both community ( ahupua' $a$ ) and regional (moku) scales, to demonstrate the holistic value of restoring this system in the 21 st century. Finally, research into circular economies could incorporate the concepts examined here into the development of more sustainable economic models in the context of capitalism as humanity moves forward in the Anthropocene.

Responses to this article can be read online at: http://www.ecologyandsociety.org/issues/responses. php/11539

\section{Acknowledgments:}

We acknowledge the mo'omana'o (epistemologies) and mo'onau'auao (lineal wisdom) of several hulu kupuna (revered elders), who have since passed on, that have been foundational to the concepts expressed in this paper. Most notable among them are Kumu Hula John Kaimikaua, Eddie Kaanaana, Thomas Hashimoto, Alice Hewitt, and Jerry Kaluhiwa. We also express our deep appreciation for Kamuela Enos, Eric Enos, "Mac" Poepoe, 'Aulani Wilhelm, Carlos Andrade, Nālani Minton, Yvonne and Keoki Carter, Kamanamaikalani Beamer, Mehana Vaughan, Peter Vitousek, Joshua Madin, Alan Friedlander, Jade Delevaux, Makena Coffman, Katharyn E. Boyer, Christopher Sabine, and Alan Carpenter for influencing the thoughts that were explored in this paper. Finally, this publication honors the centennial celebration of the life of Professor Isabella Kanakea Aiona Abbott, the first Native Hawaiian to receive a Ph.D. in science. This Indigenous woman, native speaker, and cultural practitioner paved the path for Native Hawaiians in science, as well as for women in botany, phycology, and ethnobotany. She saw the importance of marine plants in Hawaiian coastal ecosystems and gave us the tools, via her scholarship, to study mechanistic linkages between land and coastal productivity. Isabella Kanakea Aiona Abbott was a teacher and mentor to several of the authors of this concept paper. We endeavor to honor her legacy.

\section{Data Availability Statement:}

There are no data or code in this synthesis manuscript.

\section{LITERATURE CITED}

Abbott, I. A. 1992. Lā̄au Hawai $i$ : traditional Hawaiian uses of plants. Bishop Museum Press: Honolulu, Hawaii, USA.

Abbott, I. A. 1996. Limu: an ethnobotanical study of some Hawaiian seaweeds. National Tropical Botanical Garden: Lawai, Hawaii, USA.

Adolf, J. E., J. Burns, J. K. Walker, and S. Gamiao. 2019. Near shore distributions of phytoplankton and bacteria in relation to submarine groundwater discharge-fed fishponds, Kona coast, Hawai'i, USA. Estuarine, Coastal and Shelf Science 219:341-353. https://doi.org/10.1016/j.ecss.2019.01.021

Altieri, M. A. 1999. The ecological role of biodiversity in agroecosystems. Agriculture, Ecosystems and Environment 74 (1-3):19-31. https://doi.org/10.1016/S0167-8809(99)00028-6

Altieri, M. A. 2004. Linking ecologists and traditional farmers in the search for sustainable agriculture. Frontiers in Ecolology and the Environment 2(1):35-42. https://doi.org/10.1890/1540-9295 (2004)002[0035:LEATFI]2.0.CO;2 
Amato, D. W., J. M. Bishop, C. R. Glenn, H. Dulai, and C. M. Smith. 2016. Impact of submarine groundwater discharge on marine water quality and reef biota of Maui. Plos One 11(11): e0165825. https://doi.org/10.1371/journal.pone.0165825

Attrill, M. J., and S. D. Rundle. 2002. Ecotone or ecocline: ecological boundaries in estuaries. Estuarine, Coastal and Shelf Science 55(6):929-936. https://doi.org/10.1006/ecss.2002.1036

Bahr, K. D., P. L. Jokiel, and R. J. Toonen. 2015. The unnatural history of Kāne'ohe Bay: coral reef resilience in the face of centuries of anthropogenic impacts. PeerJ 3:e950. https://doi. org/10.7717/peerj.950

Barnes, R. S. K., and R. N. Hughes. 1999. An introduction to marine ecology. Third edition. Blackwell Science, Oxford, UK. https://doi.org/10.1002/9781444313284

Baulcomb, C., R. Fletcher, A. Lewis, E. Akoglu, L. Robinson, A. von Almen, S. Hussain, and K. Glenk. 2015. A pathway to identifying and valuing cultural ecosystem services: an application to marine food webs. Ecosystem Services 11:128-139. https://doi.org/10.1016/j.ecoser.2014.10.013

Berkes, F. 2018. Sacred ecology. Fourth edition. Routledge: New York, New York, USA.

Berkes, F., and C. Folke, editors. 1998. Linking social and ecological systems: management practices and social mechanisms for building resilience. Cambridge University Press, Cambridge, UK.

Bird, C. E., E. C. Franklin, C. M. Smith, and R. J. Toonen. 2013. Between tide and wave marks: a unifying model of physical zonation on littoral shores. PeerJ 1:e154. https://doi.org/10.7717/ peerj. 154

Blok, V. 2017. Earthing technology: towards an eco-centric concept of biomimetic technologies in the Anthropocene. Techné: Research in Philosophy and Technology 21(2-3):127-149. https:// doi.org/10.5840/techne201752363

Bremer, L. L., K. Falinski, C. Ching, C. A. Wada, K. M. Burnett, K. Kukea-Shultz, N. Reppun, G. Chun, K. L. L. Oleson, and T. Ticktin. 2018. Biocultural restoration of traditional agriculture: cultural, environmental, and economic outcomes of lo i kalo restoration in He'eia, O`ahu. Sustainability 10(12):4502. https:// doi.org/10.3390/su10124502

Brown, S. L., M. R. Landry, K. E. Selph, E. J. Yang, Y. M. Rii, and R. R. Bidigare. 2008. Diatoms in the desert: plankton community response to a mesoscale eddy in the subtropical North Pacific. Deep-Sea Research II 55(10-13):1321-1333. http://doi. org/10.1016/j.dsr2.2008.02.012

Brownstein, G., C. Johns, A. Fletcher, D. Pritchard, and P. D. Erskine. 2015. Ecotones as indicators: boundary properties in wetland-woodland transition zones. Community Ecology 16 (2):235-243. https://doi.org/10.1556/168.2015.16.2.11

Burnett, K. M., T. Ticktin, L. L. Bremer, S. A. Quazi, C. Geslani, C. A. Wada, N. Kurashima, L. Mandle, P. Pascua, T. Depraetere, D. Wolkis, M. Edmonds, T. Giambelluca, K. Falinski, and K. B. Winter. 2019. Restoring to the future: environmental, cultural, and management trade-offs in historical versus hybrid restoration of a highly modified ecosystem. Conservation Letters 12(1): e12606. https://doi.org/10.1111/conl.12606
Burney, D. A., H. F. James, L. P. Burney, S. L. Olson, W. Kikuchi, W. L. Wagner, M. Burney, D. McCloskey, D. Kikuchi, F. V. Grady, R. Gage II, and R. Nishek. 2001. Fossil evidence from a diverse biota from Kaua $i$ and its transformation since human arrival. Ecological Monographs 71(4):615-641. https://doi.org/10.1890/0012-9615 (2001)071[0615:FEFADB]2.0.CO;2

Burney, D. A., and W. K. P. Kikuchi. 2006. A millennium of human activity at Makauwahi Cave, Māhāūlepū, Kauaūi. Human Ecology 34:219-247. https://doi.org/10.1007/s10745-006-9015-3

Chan, K. M. A., P. Balvanera, K. Benessaiah, M. Chapman, S. Díaz, E. Gómez-Baggethun, R. Gould, N. Hannahs, K. Jax, S. Klain, G. W. Luck, B. Martín-López, B. Muraca, B. Norton, K. Ott, U. Pascual, T. Satterfield, M. Tadaki, J. Taggart, and N. Turner. 2016. Opinion: Why protect nature? Rethinking values and the environment. Proceedings of the National Academy of Sciences 113(6):1462-1465. https://doi.org/10.1073/pnas.1525002113

Chang, K., K. B. Winter, and N. K. Lincoln. 2019a. Hawai' i in focus: navigating pathways in global biocultural leadership. Sustainability 11(1):283. https://doi.org/10.3390/su11010283

Chang, K. K. J., C. K. H. Young, B. F. Asuncion, W. K. Ito, K. B. Winter, and W. C. Tanaka. 2019b. Kua'āina Ulu 'Auamo: grassroots growing through shared responsibility. In D. A. Mihesuah and E. Hoover, editors. Indigenous food sovereignty in the United States: restoring cultural knowledge, protecting environments, and regaining health. University of Oklahoma Press, Norman, Oklahoma, USA.

Colding, J., and C. Folke. 2001. Social taboos: "invisible" systems of local resource management and biological conservation. Ecological Applications 11(2):584-600. https://doi.org/10.1890/1051-0761 (2001)011[0584:STISOL]2.0.CO;2

Colding, J., C. Folke, and T. Elmqvist. 2003. Social institutions in ecosystem management and biodiversity conservation. Tropical Ecology 44(1):25-41.

Coleman, R. R. 2019. Patterns of connectivity in coral reef fishes across three spatial scales. Dissertation. University of Hawai'i at Mānoa, Honolulu, Hawaii, USA. [online] URL: https://search.proquest.com/openview/143ad11230a6ca0c3ba4836eff5deaf6/1?pq-origsite $=$ gscholar $\& \mathrm{cbl}=18750 \&$ diss $=\mathrm{y}$

Comberti, C., T. F. Thornton, V. Wyllie de Echeverria, and T. Patterson. 2015. Ecosystem services or services to ecosystems? Valuing cultivation and reciprocal relationships between humans and ecosystems. Global Environmental Change 34:247-262. https:// doi.org/10.1016/j.gloenvcha.2015.07.007

Connell, J. H. 1978. Diversity in tropical rain forests and coral reefs. Science 199(4335):1302-1310. https://doi.org/10.1126/ science.199.4335.1302

Costa-Pierce, B. A. editor. 2008. Ecological aquaculture: the evolution of the blue revolution. Blackwell, Oxford, UK. https:// doi.org/10.1002/9780470995051

Cowie, R. H., and B. S. Holland. 2008. Molecular biogeography and diversification of the endemic terrestrial fauna of the Hawaiian Islands. Philosophical Transaction of the Royal Society B 363:3363-3376. https://doi.org/10.1098/rstb.2008.0061

Dailer, M. L., J. E. Smith, and C. M. Smith. 2012. Responses of bloom forming and non-bloom forming macroalgae to nutrient 
enrichment in Hawai'i, USA. Harmful Algae 17:111-125. https:// doi.org/10.1016/j.hal.2012.03.008

DHM Inc.; Hawaii Coastal Zone Management Program; Hawaii Division of State Parks, Outdoor Recreation, and Historic Sites; and Bernice Pauahi Bishop Museum. 1990. Hawaiian fishpond study: islands of O'ahu, Moloka'i, and Hawai'i. DHM Planners, Honolulu, Hawaii, USA.

Díaz, S., U. Pascual, M. Stenseke, B. Martín-López, R. T. Watson, Z. Molnár, R. Hill, K. M. A. Chan, I. A. Baste, K. A. Brauman, S. Polasky, A. Church, M. Lonsdale, A. Larigauderie, P. W. Leadley, A. P. E. van Oudenhoven, F. van der Plaat, M. Schröter, S. Lavorel, Y. Aumeeruddy-Thomas, E. Bukvareva, K. Davies, S. Demissew, G. Erpul, P. Failler, C. A. Guerra, C. L. Hewitt, H. Keune, S. Lindley, and Y. Shirayama. 2018. Assessing nature's contributions to people. Science 359(6373):270-272. https://doi. org/10.1126/science.aap8826

Doty, M. S., and M. Oguri. 1956. The island mass effect. ICES Journal of Marine Science 22(1):33-37. https://doi.org/10.1093/ icesjms/22.1.33

Duarte, T. K., S. Pongkijvorasin, J. Roumasset, D. Amato, and K. Burnett. 2010. Optimal management of a Hawaiian coastal aquifer with nearshore marine ecological interactions. Water Resources Research 46(11):W11545. https://doi.org/10.1029/2010WR009094

Franklin, E. C., P. L. Jokiel, and M. J. Donahue. 2013. Predictive modeling of coral distribution and abundance in the Hawaiian Islands. Marine Ecology Progress Series 481:121-132. https://doi. org/10.3354/meps 10252

Friedlander, A. M., and J. D. Parrish. 1998. Habitat characteristics affecting fish assemblages on a Hawaiian coral reef. Journal of Experimental Marine Biology and Ecology 224(1):1-30. https:// doi.org/10.1016/S0022-0981(97)00164-0

Friedlander, A., K. Poepoe, K. Poepoe, K. Helm, P. Bartram, J. Maragos, and I. Abbott. 2002. Application of Hawaiian traditions to community-based fishery management. Pages 813-815 in Proceedings of the Ninth International Coral Reef Symposium, Bali, 23-27 October 2000, volume 2. WorldFish Center ReefBase Project, Penang, Malaysia.

Gliessman, S. R. 2014. Agroecology: the ecology of sustainable food systems. Third edition. CRC Press, Boca Raton, Florida, USA. https://doi.org/10.1201/b17881

Gon, S. M. III, S. L. Tom, and U. Woodside. 2018. 'Āina momona, honua au loli-productive lands, changing world: using the Hawaiian footprint to inform biocultural restoration and future sustainability in Hawai'i. Sustainability 10(10):3420. https://doi. org/10.3390/su10103420

Gon, S. M. III, and K. B. Winter. 2019. A Hawaiian renaissance that could save the world. American Scientist 107:232-239. https:// doi.org/10.1511/2019.107.4.232

Gonschor, L., and K. Beamer. 2014. Toward in inventory of ahupua'a in the Hawaiian Kingdom: a survey of nineteenth- and early twentieth-century cartographic and archival records of the Island of Hawai' i. Hawaiian Journal of History 48:53-87. [online] URL: http://hdl.handle.net/10524/47256
Gould, R. K., M. Pai, B. Muraca, and K. M. A. Chan. 2019. He 'ike 'ana ia i ka pono (it is a recognizing of the right thing): how one indigenous worldview informs relational values and social values. Sustainability Science 14:1213-1232. https://doi. org/10.1007/s11625-019-00721-9

Gove, J. M., M. A. McManus, A. B. Neuheimer, J. J. Polovina, J. C. Drazen, C. R. Smith, M. A. Merrifield, A. M. Freidlander, J. S. Ehses, C. W. Young, A. K. Dillon, and G. J. Williams. 2016. Near-island biological hotspots in barren ocean basins. Nature Communications 7:10581. https://doi.org/10.1038/ncomms10581

Gross, M. 2012. The mysteries of the diatoms. Current Biology 22(15):R581-R585. https://doi.org/10.1016/j.cub.2012.07.041

Handy, E. S. C., E. G. Handy, and M. K. Pukui. 1972. Native planters in old Hawai $i$ : their life, lore, and environment. Bishop Museum Press, Honolulu, Hawaii, USA.

Hiatt, R. W. 1947a. Food-chains and the food cycle in Hawaiian fish ponds.-Part I. The food and feeding habits of mullet (Mugil cephalus), milkfish (Chanos chanos), and the ten-pounder (Elops machnata). Transactions of the American Fisheries Society 74 (1):250-261. https://doi.org/10.1577/1548-8659(1944)74[250:FATFCI] 2.0.CO 2

Hiatt, R. W. 1947b. Food-chains and the food cycle in Hawaiian fish ponds.-Part II. Biotic interaction. Transactions of the American Fisheries Society 74(1):262-280. https://doi. org/10.1577/1548-8659(1944)74[262:FATFCI]2.0.CO;2

Jacobi, J. D., J. P. Price, L. B. Fortini, S. M. Gon III, P. Berkowitz. 2017. Baseline land cover. Pages 9-20 in P. C. Selmants, C. P. Giardina, J. D. Jacobi, and Z. Zhu, editors. Baseline and projected future carbon storage and carbon fluxes in ecosystems of Hawai $i$. Professional Paper 1834. U.S. Geological Survey, Reston, Virginia, USA. [online] URL: https://pubs.usgs.gov/pp/1834/a/ pp1834.pdf

Jarvis, D. I., A. H. D. Brown, P. H. Cuong, L. Collado-Panduro, L. Latournerie-Moreno, S. Gyawali, T. Tanto, M. Sawadogo, I. Mar, M. Sadiki, N. T.-N. Hue, L. Arias-Reyes, D. Balma, J. Bajracharya, F. Castillo, D. Rijal, L. Belqadi, R. Rana, S. Saidi, J. Ouedraogo, R. Zangre, K. Rhrib, J. L. Chavez, D. Schoen, B. Sthapit, P. De Santis, C. Fadda, and T. Hodgkin. 2008. A global perspective of the richness and evenness of traditional cropvariety diversity maintained by farming communities. Proceedings of the National Academy of Sciences 105 (14):5326-5331. https://doi.org/10.1073/pnas.0800607105

Junk, W., P. B. Bayley, and R. E. Sparks. 1989. The flood pulse concept in river-floodplain systems. Pages 110-127 in D. P. Dodge, editor. Proceedings of the International Large River Symposium ( $L A R S$ ). Canadian Special Publication of Fisheries and Aquatic Sciences. Department of Fisheries and Oceans, Ottawa, Canada. [online] URL: http://www.dfo-mpo.gc.ca/Library/111846.pdf

Kagawa, A. K., and P. M. Vitousek. 2012. The ahupua'a of Puanui: a resource for understanding Hawaiian rain-fed agriculture. Pacific Science 66(2):161-172. https://doi.org/10.2984/66.2.6

Kagawa-Viviani, A. K., N. K. Lincoln, S. Quintus, M. P. Lucas, and T. W. Giambelluca. 2018. Spatial patterns of seasonal crop production suggest coordination within and across dryland agricultural systems of Hawai'i Island. Ecology and Society 23 (3):20. https://doi.org/10.5751/ES-10369-230320 
Kahaulelio, D., and M. K. Pukui. 2006. Ka 'oihana lawai'a: Hawaiian fishing traditions. Bishop Museum Press, Honolulu, Hawaii, USA.

Kamakau, S. M. 1976. The works of the people of old: na hana a ka po'e kahiko. Bishop Museum Press, Honolulu, Hawaii, USA.

Kamakau, S. M., D. B. Barrère, and M. K. Pukui. 1964. Ka po'e kahiko: the people of old. Bishop Museum Press, Honolulu, Hawaii, USA.

Kealiikanakaoleohaililani, K., N. Kurashima, K. S. Francisco, C. P. Giardina, R. P. Louis, H. McMillen, C. K. Asing, K. Asing, T. A. Block, M. Browning, K. Camara, L. Camara, M. L. Dudley, M. Frazier, N. Gomes, A. E. Gordon, M. Gordon, L. Heu, A. Irvine, N. Kaawa, S. Kirkpatrick, E. Leucht, C. H. Perry, J. Replogle, L.-L. Salbosa, A. Sato, L. Schubert, A. Sterling, A. L. Uowolo, J. Uowolo, B. Walker, A. N. Whitehead, and D. Yogi. 2018. Ritual + sustainability science? A portal into the science of aloha. Sustainability 10(10):3478. https://doi.org/10.3390/ $\underline{\text { su10103478 }}$

Kelly, M. 1983. Namala o Kona: gardens of Kona. Bishop Museum Press, Honolulu, Hawaii, USA.

Kikiloi, K. 2003. A new synthesis in oceanic domestication: the symbiotic development of loko ita aquaculture in pre-contact Oceania. Traditional Marine Resource Management and Knowledge Information Bulletin 15:3-10. [online] URL: https:// coastfish.spc.int/en/publications/bulletins/traditional-management/207traditional-information-bulletin-15

Kikuchi, W. K. 1976. Prehistoric Hawaiian fishponds. Science 193:295-299. https://doi.org/10.1126/science.193.4250.295

Kimura, L. K., and R. N. Mahuiki. 1975. Ka leo Hawai $i$. [radio broadcast]. A Hawaiian language program on KCCN 1420AM, episode 104. Archived at University of Hawai'i at Mānoa, Honolulu, Hawaii, USA.

Kirch, P. V., J. Coil, A. S. Hartshorn, M. Jeraj, P. M. Vitousek, and O. A. Chadwick. 2005. Intensive dryland farming on the leeward slopes of Haleakala, Maui, Hawaiian Islands: archaeological, archaeobotanical, and geochemical perspectives. World Archaeology 37(2):240-258. https://doi.org/10.1080/00438240500095074

Kirch, P. V., A. S. Hartshorn, O. A. Chadwick, P. M. Vitousek, D. R. Sherrod, J. Coil, L. Holm, and W. D. Sharp. 2004. Environment, agriculture, and settlement patterns in a marginal Polynesian landscape. Proceedings of the National Academy of Sciences 101(26):9936-9941. https://doi.org/10.1073/pnas.0403470101

Kirch, P. V., J. Holson, and A. Baer. 2009. Intensive dryland agriculture in Kaupō, Maui, Hawaiian Islands. Asian Perspectives 48(2):265-290. [online] URL: http://hdl.handle.net/10125/29089

Kirch, P. V., J. Holson, P. Cleghorn, T. D. Schneider, and O. Chadwick. 2013. Five centuries of dryland farming and floodwater irrigation at Hōkūkano Flat, Auwahi, Maui Island. Hawaiian Archaeology 13:69-102.

Kittinger, J. N., J. M. Pandolfi, J. H. Blodgett, T. L. Hunt, H. Jiang, K. Maly, L. E. McClenachan, J. K. Schultz, and B. A. Wilcox. 2011. Historical reconstruction reveals recovery in Hawaiian coral reefs. Plos One 6(10):e25460. https://doi. org/10.1371/journal.pone.0025460
Koshiba, S., M. Besebes, K. Soaladaob, A. L. Isechal, S. Victor, and Y. Golbuu. 2013. Palau's taro fields and mangroves protect the coral reefs by trapping eroded fine sediment. Wetlands Ecology and Management 21:157-164. https://doi.org/10.1007/s11273-013-9288-4

Kurashima, N., L. Fortini, and T. Ticktin. 2019. The potential of indigenous agricultural food production under climate change in Hawai i. Nature Sustainability 2:191-199. https://doi.org/10.1038/ s41893-019-0226-1

Kurashima, N., J. Jeremiah, A. N. Whitehead, J. Tulchin, M. Browning, and T. Duarte. 2018. 'Āina kaumaha: the maintenance of ancestral principles for 21st century indigenous resource management. Sustainability 10(11):3975. https://doi.org/10.3390/ su10113975

Ladefoged, T. N., M. D. McCoy, G. P. Asner, P. V. Kirch, C. O. Puleston, O. A. Chadwick, and P. M. Vitousek. 2011. Agricultural potential and actualized development in Hawai $\mathrm{i}$ : an airborne LiDAR survey of the leeward Kohala field system (Hawai $i$ Island). Journal of Archaeological Science 38(12):3605-3619. https://doi.org/10.1016/j.jas.2011.08.031

Ladefoged, T. N., A. Preston, P. M. Vitousek, O. A. Chadwick, J. Stein, M. W. Graves, and N. Lincoln. 2018. Soil nutrients and preEuropean contact agriculture in the leeward Kohala field system, Island of Hawai i. Archaeology in Oceania 53(1):28-40. https:// doi.org/10.1002/arco.5138

Ladefoged, T. N., C. M. Stevenson, S. Haoa, M. Mulrooney, C. Puleston, P. M. Vitousek, and O. A. Chadwick. 2010. Soil nutrient analysis of Rapa Nui gardening. Archaeology in Oceania 45 (2):80-85. https://doi.org/10.1002/j.1834-4453.2010.tb00082.x

Lee, C. T., S. Tuljapurkar, and P. M. Vitousek. 2006. Risky business: temporal and spatial variation in preindustrial dryland agriculture. Human Ecology 34:739-763. https://doi.org/10.1007/ s10745-006-9037-X

Lewis, S. L., and M. A. Maslin. 2015. Defining the Anthropocene. Nature 519:171-180. https://doi.org/10.1038/nature14258

Lincoln, N. K. 2020. Agroforestry form and ecological adaptation in ancient Hawai'i: extent of the pākukui swidden system of Hāmākua, Hawai'i Island. Agricultural Systems 181:102808. https://doi.org/10.1016/j.agsy.2020.102808

Lincoln, N., O. Chadwick, and P. Vitousek. 2014. Indicators of soil fertility and opportunities for pre-contact agriculture in Kona, Hawai'i. Ecosphere 5(4):42. https://doi.org/10.1890/ ES13-00328.1

Lincoln, N. K., A. Kagawa-Viviani, K. Marshall, and P. M. Vitousek. 2017. Observations of sugarcane and knowledge specificity in traditional Hawaiian cropping systems. Pages 273-282 in R. Murphy, editor. Sugarcane: production systems, uses, and economic impact. Nova Science Publishers, Hauppauge, New York, USA.

Lincoln, N., and T. Ladefoged. 2014. Agroecology of pre-contact Hawaiian dryland farming: the spatial extent, yield and social impact of Hawaiian breadfruit groves in Kona, Hawai'i. Journal of Archaeological Science 49:192-202. https://doi.org/10.1016/j. jas.2014.05.008

Lincoln, N. K., J. Rossen, P. Vitousek, J. Kahoonei, D. Shapiro, K. Kalawe, M. Pai, K. Marshall, and K. Meheula. 2018. 
Restoration of 'āina malo'o on Hawai'i Island: expanding biocultural relationships. Sustainbility 10(11):3985. https://doi. org/10.3390/su10113985

Lincoln, N. K., and P. M. Vitousek 2017. Indigenous Polynesian agriculture in Hawaii. In Oxford Research Encyclopedias: Environmental Science. Oxford University Press, Oxford, UK. https://doi.org/10.1093/acrefore/9780199389414.013.376

Lindeman, R. L. 1942. The trophic-dynamic aspect of ecology. Ecology 23(4):399-417. https://doi.org/10.2307/1930126

Loke, M. K., and P. Leung. 2013. Hawai'i's food consumption and supply sources: benchmark estimates and measurement issues. Agricultural Food and Economics 1:10. https://doi. org/10.1186/2193-7532-1-10

Madin, E. M. P., K. Precoda, A. R. Harborne, T. B. Atwood, C. M. Roelfsema, and O. J. Luiz. 2019. Multi-trophic species interactions shape seascape-scale coral reef vegetation patterns. Frontiers in Ecology and Evolution 7:102. https://doi.org/10.3389/ fevo.2019.00102

Maltby, E., and M. C. Acreman. 2011. Ecosystem services of wetlands: pathfinder for a new paradigm. Hydrological Sciences Journal 56(8):1341-1359. https://doi.org/10.1080/02626667.2011.631014

Maly, K., and O. Maly. 2003a. Hana ka lima, 'ai ka waha: a collection of historical accounts and oral history interviews with kama'äina residents and fisher-people of lands in the Halele ' $a$ Napali region on the island of Kaua i. Kumu Pono Associates report for the Nature Conservancy and the National Tropical Botanical Gardens-Limahuli Gardens. Kumu Pono Associates, Hilo, Hawaii, USA. [online] URL: http://ulukau.org/elib/cgi-bin/ library? $=\mathrm{d}-0$ maly4-000Sec--11 haw-50-20-frameset-bookmaly $+2003-1-011$ escapewin $\& \mathrm{a}=\mathrm{d} \& \mathrm{p} 2=$ hardcopy $\&$ toc $=2$

Maly, K., and O. Maly. 2003b. Ka hana lawai' a a me nā ko'a o nā kai' ewalu: a history of fishing practices and marine fisheries of the Hawaiian Islands. Volume 1. Kumu Pono Associates report for the Nature Conservancy of Hawaici. Nature Conservancy of Hawai'i, Honolulu, Hawaii, USA. [online] URL: http://ulukau. org/elib/cgi-bin/library?e=d-0maly1-000Sec--11en-50-20-framesetbook-maly $+2003-1-011$ escapewin $\& a=d \& p 2=$ hardcopy $\&$ toc $=2$

Marshall, K., C. Koseff, A. L. Roberts, A. Lindsey, A. K. KagawaViviani, N. K. Lincoln, and P. M. Vitousek. 2017. Restoring people and productivity to Puanui: challenges and opportunities in the restoration of an intensive rain-fed Hawaiian field system. Ecology and Society 22(2):23. https://doi.org/10.5751/ES-09170-220223

McCoy, D., M. A. McManus, K. Kotubetey, A. H. Kawelo, C. Young, B. D'Andrea, K. C. Ruttenberg, and R. 'A. Alegado. 2017. Large-scale climatic effects on traditional Hawaiian fishpond aquaculture. Plos One 12(11):e0187951. https://doi.org/10.1371/ journal.pone. 0187951

McGregor, D. P. 2007. Nā kua'āaina: living Hawaiian culture. University of Hawai'i Press, Honolulu, Hawaii, USA.

McLeod, K., and H. Leslie, editors. 2009. Ecosystem-based management for the oceans. Island Press, Washington, D.C., USA.

Minton, N., producer, and Nā Maka o ka 'Āina, director. 1992. Ahupua'a, fishponds, and lo $i$. [documentary film]. Nā‘ālehu, Hawaii, USA.
Mitsch, W. J. 2012. What is ecological engineering? Ecological Engineering 45:5-12. https://doi.org/10.1016/j.ecoleng.2012.04.013

Möhlenkamp, P., C. K. Beebe, M. A. McManus, A. H. Kawelo, K. Kotubetey, M. Lopez-Guzman, C. E. Nelson, and R. 'A. Alegado. 2019. Kū hou kuapā: cultural restoration improves water budget and water quality dynamics in He'eia fishpond. Sustainability 11(1):161. https://doi.org/10.3390/su11010161

Molnar, Z., and F. Berkes. 2018. Role of traditional ecological knowledge in linking cultural and natural capital in cultural landscapes. Pages 183-193 in M.-L. Paracchini, P. C. Zingari, and C. Blasi, editors. Reconnecting natural and cultural capital: contributions from science and policy. Publications Office of the European Union, Luxembourg. [online] URL: https://ec.europa. eu/jrc/en/publication/re-connecting-natural-and-cultural-capitalcontributions-science-and-policy

Nakamura, F., F. J. Swanson, and S. M. Wondzell. 2000. Disturbance regimes of stream and riparian systems - a disturbance-cascade perspective. Hydological Processes 14 (16-17):2848-2860. https://doi.org/10.1002/1099-1085(200011/12) 14:16/17<2849::AID-HYP123>3.0.CO;2-X

Nakuina, E. M. 2007. Ancient Hawaiian water rights: and some of the customs pertaining to them. Organization and Environment 20(4):506-509. Reprinted from Thrums Hawaiian Annual (1893, pages 79-84). https://doi.org/10.1177/1086026607309681

Nelson, G. C., E. Bennett, A. A. Berhe, K. Cassman, R. DeFries, T. Dietz, A. Dobermann, A. Dobson, A. Janetos, M. Levy, D. Marco, N. Nakicenovic, B. O’Neill, R. Norgaard, G. PetschelHeld, D. Ojima, P. Pingali, R. Watson, and M. Zurek. 2006. Anthropogenic drivers of ecosystem change: an overview. Ecology and Society 11(2):29. https://doi.org/10.5751/ES-01826-110229

Ostrom, E. 1990. Governing the commons: the evolution of institutions for collective action. Cambridge University Press, Cambridge, UK.

Pascua, P., H. McMillen, T. Ticktin, M. Vaughan, and K. B. Winter. 2017. Beyond services: a process and framework to incorporate cultural, genealogical, place-based, and indigenous relationships in ecosystem service assessments. Ecosystem Services 26(B):465-475. https://doi.org/10.1016/j.ecoser.2017.03.012

Poepoe, K. K., P. K. Bartram, and A. M. Friedlander. 2003. The use of traditional Hawaiian knowledge in the contemporary management of marine resources. Pages 328-339 in N. Haggan, C. Brignall, and L. Wood, editors. Putting fisher's knowledge to work: conference proceedings August 27-30, 2001. Fisheries Center Research Reports 11(1). University of British Columbia, Vancouver, Canada. [online] URL: https://open.library.ubc.ca/ media/download/pdf/52383/1.0074793/1

Pukui, M. K. 1983.'Ōlelo no'eau: Hawaiian proverbs and poetical sayings. Bishop Museum Press, Honolulu, Hawaii, USA.

Pukui, M. K., and S. H. Elbert. 1986. Hawaiian dictionary: Hawaiian-English, English-Hawaiian. University of Hawaii Press, Honolulu, Hawaii, USA.

Pukui, M. K., E. W. Haertig, and C. A. Lee. 1972. Nānāi ke kumu: look to the source. Volume 1. Hui Hānai, Honolulu, Hawaii, USA.

Quintus, S., J. Huebert, P. V. Kirch, N. K. Lincoln, and J. Maxwell. 2019. Qualities and contributions of agroforestry practices and 
novel forests in pre-European Polynesia and the Polynesian outliers. Human Ecology 47(6):811-825. https://doi.org/10.1007/ s10745-019-00110-X

Rii, Y. M., S. L. Brown, F. Nencioli, V. Kuwahara, T. Dickey, D. M. Karl, and R. R. Bidigare. 2008. The transient oasis: nutrientphytoplankton dynamics and particle export in Hawaiian lee cyclones. Deep Sea Research Part II: Topical Studies in Oceanography 55(10-13):1275-1290. https://doi.org/10.1016/j. $\underline{\mathrm{dsr} 2.2008 .01 .013}$

Robbins, P., A. Chhatre, and K. Karanth. 2015. Political ecology of commodity agroforests and tropical biodiversity. Conservation Letters 8(2):77-85. https://doi.org/10.1111/conl.12169

Robson, J. P., and F. Berkes. 2011. Exploring some of the myths of land use change: Can rural to urban migration drive declines in biodiversity? Global Environmental Change 21(3):844-854. https://doi.org/10.1016/j.gloenvcha.2011.04.009

Rockström, J., W. Steffen, K. Noone, Å. Persson, F. S. Chapin III, E. F. Lambin, T. M. Lenton, M. Scheffer, C. Folke, H. J. Schellnhuber, B. Nykvist, C. A. de Wit, T. Hughes, S. van der Leeuw, H. Rodhe, S. Sörlin, P. K. Snyder, R. Costanza, U. Svedin, M. Falkenmark, L. Karlberg, R. W. Corell, V. J. Fabry, J. Hansen, B. Walker, D. Liverman, K. Richardson, P. Crutzen, and J. A. Foley . 2009. A safe operating space for humanity. Nature 461 (7263):472-475. https://doi.org/10.1038/461472a

Rodgers, K. S., P. L. Jokiel, C. E. Bird, and E. K. Brown. 2010. Quantifying the condition of Hawaiian coral reefs. Aquatic Conservation in Marine and Freshwater Ecosystems 20(1):93-105. https://doi.org/10.1002/aqc.1048

Sanders, D., C. G. Jones, E. Thébault, T. J. Bouma, T. van der Heide, J. van Belzen, and S. Barot. 2014. Integrating ecosystem engineering and food webs. Oikos 123(5):513-524. https://doi. org/10.1111/j.1600-0706.2013.01011.x

Scheffler, T. E., and J. P. Lockwood. 2014. The geometry of Loko Kuapā Kìholo: the regional significance and cultural context of a Royal Hawaiian fishpond. Journal of Pacific Archaeology 5 (1):39-51. [online] URL: https://pacificarchaeology.org/index. php/journal/article/view/119

Selkoe, K. A., O. E. Gaggiotti, E. A. Treml, J. L. K. Wren, M. K. Donovan, Hawai i Reef Connectivity Consortium, and R. J. Toonen. 2016. The DNA of coral reef biodiversity: predicting and protecting genetic diversity of reef assemblages. Proceedings of the Royal Society B 283(1829):20160354. https://doi. org/10.1098/rspb.2016.0354

Smith, J. E., C. L. Hunter, and C. M. Smith. 2002. Distribution and reproductive characteristics of nonindigenous and invasive marine algae in the Hawaiian Islands. Pacific Science 56 (3):299-315. https://doi.org/10.1353/psc.2002.0030

Sproat, D. K. 2015. From Wai to Kānāwai: water law in Hawaii. Pages 951-1109 in M. K. MacKenzie, S. K. Serrano, D. K. Sproat, A. K. Obrey, and A. K. Poai, editors. Native Hawaiian law: a treatise. Kamehameha Publishing, Honolulu, Hawaii, USA.

Sterling, E. J., C. Filardi, A. Toomey, A. Sigouin, E. Betley, N. Gazit, J. Newell, S. Albert, D. Alvira, N. Bergamini, M. Blair, D. Boseto, K. Burrows, N. Bynum, S. Caillon, J. E. Caselle, J. Claudet,
G. Cullman, R. Dacks, P. B. Eyzaguirre, S. Gray, J. Herrera, P. Kenilorea, K. Kinney, N. Kurashima, S. Macey, C. Malone, S. Mauli, J. McCarter, H. McMillen, P. Pascua, P. Pikacha, A. L. Porzecanski, P. de Robert, M. Salpeteur, M. Sirikolo, M. H. Stege, K. Stege, T. Ticktin, R. Vave, A. Wali, P. West, K. B. Winter, and S. D. Jupiter. 2017. Biocultural approaches to well-being and sustainability indicators across scales. Nature Ecology and Evolution 1:1798-1806. https://doi.org/10.1038/s41559-017-0349-6

Summers, C. C. 1964. Hawaiian fishponds. Bishop Museum Press, Honolulu, Hawaii, USA.

Ticktin, T., S. Quazi, R. Dacks, M. Tora, A. McGuigan, Z. Hastings, and A. Naikatini. 2018. Linkages between measures of biodiversity and community resilience in Pacific island agroforests. Conservation Biology 32(5):1085-1095. https://doi. org/10.1111/cobi.13152

Turner, N. J., I. J. Davidson-Hunt, and M. O'Flaherty. 2003. Living on the edge: ecological and cultural edges as sources of diversity for social-ecological resilience. Human Ecology 31 (3):439-461. https://doi.org/10.1023/A:1025023906459

Van Looy, K., J. D. Tonkin, M. Floury, C. Leigh, J. Soininen, S. Larsen, J. Heino, N. L. Poff, M. Delong, S. C. Jähnig, T. Datry, N. Bonada, J. Rosebery, A. Jamoneau, S. J. Ormerod, K. J. Collier, and C. Wolter. 2019. The three Rs of river ecosystem resilience: resources, recruitment, and refugia. River Research and Applications 35(2):107-120. https://doi.org/10.1002/rra.3396

Vitousek, P. M., O. A. Chadwick, G. Hilley, P. V. Kirch, and T. N. Ladefoged. 2010. Erosion, geological history, and indigenous agriculture: a tale of two valleys. Ecosystems 13(5):782-793. https://doi.org/10.1007/s10021-010-9354-1

Welch, E. M., H. Dulai, A. El-Kadi, and C. K. Shuler. 2019. Submarine groundwater discharge and stream baseflow sustain pesticide and nutrient fluxes in Faga'alu Bay, American Samoa. Frontiers in Environmental Science 7:162. https://doi.org/10.3389/ fenvs.2019.00162

Winter, K. B. 2012. Kalo [Hawaiian taro, Colocasia esculenta (L.) Schott] varieties: an assessment of nomenclatural synonymy and biodiversity. Ethnobotany Resesearch and Applications 10:423-447. [online] URL: http://www.ethnobotanyjournal.org/index.php/ era/article/view/708

Winter, K. B., K. Beamer, M. B. Vaughan, A. M. Friedlander, M. H. Kido, A. N. Whitehead, M. K. H. Akutagawa, N. Kurashima, M. P. Lucas, and B. Nyberg. 2018a. The moku system: managing biocultural resources for abundance within social-ecological regions in Hawai'i. Sustainability 10(10):3554. https://doi. org/10.3390/su10103554

Winter, K. B., N. K. Lincoln, and F. Berkes. 2018b. The socialecological keystone concept: a quantifiable metaphor for understanding the structure, function, and resilience of a biocultural system. Sustainability 10(9):3294. https://doi. org/10.3390/su10093294

Winter, K. B., and M. Lucas. 2017. Spatial modeling of socialecological management zones of the ali $i$ era on the island of Kaua' $i$ with implications for large-scale biocultural conservation and forest restoration efforts in Hawai'i. Pacific Science 71 (4):457-477. https://doi.org/10.2984/71.4.5 
Winter, K. B., and W. McClatchey. 2008. Quantifying evolution of cultural interactions with plants: implications for managing diversity for resilience in social-ecological systems. Functional Ecosystems and Communities 2(Special Issue 1):1-10. [online] URL: http://www.globalsciencebooks.info/Online/GSBOnline/ images/0812/FEC 2(SI1)/FEC 2(SI1)1-10o.pdf

Winter, K. B., T. Ticktin, and S. A. Quazi. 2020. Biocultural restoration in Hawai $i$ also achieves core conservation goals. Ecology and Society 25(1):26. https://doi.org/10.5751/ES-11388-250126

Yeang, K. 2013. Ecomimicry: ecological design by imitating ecosystems. Routledge, London, UK.

Young, K. J. 2017. Mimicking nature: a review of successional agroforestry systems as an analogue to natural regeneration of secondary forest stands. Pages 179-209 in F. Montagnini, editor. Integrating landscapes: agroforestry for biodiversity conservation and food sovereignty. Springer, Cham, Switzerland. https://doi. org/10.1007/978-3-319-69371-2 8

Ziegler, A. C. 2002. Hawaiian natural history, ecology, and evolution. University of Hawaii Press, Honolulu, Hawaii, USA. https://doi.org/10.1515/9780824842437 